\title{
Potential of Anti-MUC1 Antibodies as a Targeted Therapy for Gastrointestinal Cancers
}

\author{
Mukulika Bose * and Pinku Mukherjee \\ Department of Biological Sciences, University of North Carolina, Charlotte, NC 28223, USA; pmukherj@uncc.edu \\ * Correspondence: mbose@uncc.edu
}

Received: 30 September 2020; Accepted: 3 November 2020; Published: 5 November 2020

\begin{abstract}
Gastrointestinal cancers (GI) account for 26\% of cancer incidences globally and $35 \%$ of all cancer-related deaths. The main challenge is to target cancer specific antigens. Mucins are heavily O-glycosylated proteins overexpressed in different cancers. The transmembrane glycoprotein MUC1 is the most likeable target for antibodies, owing to its specific overexpression and aberrant glycosylation in many types of cancers. For the past 30 years, MUC1 has remained a possible diagnostic marker and therapeutic target. Despite initiation of numerous clinical trials, a comprehensively effective therapy with clinical benefit is yet to be achieved. However, the interest in MUC1 as a therapeutic target remains unaltered. For all translational studies, it is important to incorporate updated relevant research findings into therapeutic strategies. In this review we present an overview of the antibodies targeting MUC1 in GI cancers, their potential role in immunotherapy (i.e., antibody-drug and radioimmunoconjugates, CAR-T cells), and other novel therapeutic strategies. We also present our perspectives on how the mechanisms of action of different anti-MUC1 antibodies can target specific hallmarks of cancer and therefore be utilized as a combination therapy for better clinical outcomes.
\end{abstract}

Keywords: MUC1; immunotherapy; monoclonal antibody; gastrointestinal cancers; CAR-T cells

\section{Global Burden of GI Cancers}

Gastrointestinal (GI) cancers collectively refer to cancers of the esophagus and stomach (gastroesophageal cancers), the colon and rectum (colorectal cancers), pancreas, liver, gallbladder, small intestine, appendix, and anus. Following lung cancer (18.4\%), colorectal cancer $(9.2 \%)$, stomach cancer $(8.2 \%)$, and liver cancer $(8.2 \%)$ form the leading causes of cancer-related deaths worldwide [1].

According to the American Cancer Society (ACS) (www.cancer.org), gastrointestinal (GI) cancers have the highest incidence and are the second leading cause of cancer-related deaths in the United States. Esophageal cancer is the seventh most commonly diagnosed cancer and the 6th leading cause of cancer-related deaths worldwide [1]. It is often detected late and there are usually no early symptoms. The overall five-year survival rate for advanced esophageal cancer in the United States is about 15\% [2]. Stomach cancer, or gastric cancer, is the fifth most common cancer in the world and the second highest cause of cancer-related deaths globally [3].

Pancreatic Cancer is the twelfth most common cancer globally and the seventh leading cause of cancer-related deaths [1]. However, in the US it is the third leading cause of cancer-related deaths and is projected to become the second by the end of the year 2020. Most of the pancreatic tumors are detected at a very advanced stage thus making it a lethal disease. It has a dismal 5\% 5-year survival rate globally, a mean life expectancy of $<6$ months, and a high degree of resistance to standard therapy. In the US the five-year survival rate is $9 \%$, which is the lowest of all major cancers. Liver cancer is the sixth most commonly diagnosed cancer and the fourth leading cause of cancer-related deaths worldwide [1]. Colorectal cancer is the third most common cancer worldwide and the second leading cause of cancer mortality [1]. 
Chemotherapy and radiation therapy alone or in combination with surgery remain the main modes of treatment so far. However, various immunotherapies are undergoing trials with monoclonal antibodies, combination therapies, CAR-T cell, dendritic cell therapies etc. In the last 40 years, the incidence and mortality of GI cancers have only increased without improvement in therapy. The main challenge is to target specific antigens that are not expressed in normal tissues. Mucins have always been shown to be key immunological players in various chronic and infectious diseases including cancer. In this review, we will provide a detailed overview of various immunotherapies developed against the mucin protein MUC1 in GI cancers including monoclonal antibodies, CAR-T cells and bi-specific antibodies that have successfully been through preclinical and clinical trials. We will also provide perspectives on how some of these antibodies target specific hallmarks of cancer so that they can be combined with other drugs for better outcomes in the clinic.

\section{MUC1 as a Target Antigen in GI Cancers}

\subsection{Structure of MUC1}

Mucins are high molecular weight glycoproteins and their main function is to lubricate epithelial cell surfaces and protect them against invading pathogens [4]. Mucins are broadly divided into secretory gel-forming mucins (MUC2, MUC5AC, MUC5B, MUC6, MUC7 and MUC19, as protective barriers for underlying mucosal cells) and membrane-bound mucins (MUC1, MUC3A, MUC3B, MUC4, MUC12, MUC13, MUC15, MUC16, MUC17, and MUC20) that have a transmembrane, N-terminal extracellular domain (ECD), and a C-terminal cytoplasmic tail. Secretory gel-forming mucins work as protective barriers for underlying mucosal cells, while membrane-bound mucins also play a key role in cell signaling pathways and cellular interactions [4-6].

Mucin 1 or MUC1 (also known as episialin, PEM, EMA, H23Ag, MCA, and CA15-3) was the first transmembrane mucin to be identified and structurally characterized [7-10]. MUC1 is a single pass type I transmembrane glycoprotein with a hyperglycosylated extracellular $\mathrm{N}$ - terminal domain that extends up to 200-500 nm from the cell surface [11,12]. Normally, MUC1 is expressed on the apical surface of glandular or luminal epithelial cells of almost all tissues including the mammary gland, stomach, lungs, esophagus, duodenum, pancreas, uterus, prostate, and the hematopoietic cells [13,14]. In healthy tissues, the extended hyperglycosylated branches of MUC1 create a physical barrier and prevent pathogenic access, thus protecting the underlying epithelia $[15,16]$. The extended sugar branches form a mucinous gel by oligomerization and protect the underlying epithelia from desiccation, $\mathrm{pH}$ changes, and invading microbes [17]. During translation, MUC1 is cleaved [18,19], and the extracellular domain with tandem repeats (25-100) is bound to the membrane by noncovalent interaction with the C-terminal domain of MUC1 (MUC1-CD) that consists of a short extracellular domain (ED), the transmembrane domain (TM) and the cytoplasmic domain (MUC1-CT). The MUC1 gene encodes a single polypeptide chain which is cleaved by auto-proteolysis process at a sea -urchin sperm protein enterokinase and agrin (SEA) domain to generate two peptide fragments and heterodimeric MUC1 [11,20]. The $\beta$ subunit or MUC1-C contains a C-terminal cytoplasmic domain (MUC1-CT) with 69 amino acids, a hydrophobic transmembrane domain (TMD) with 28 amino acids and a short extracellular domain (ECD) with 58 -amino acids that is noncovalently attached to the N-terminal extracellular domain (MUC1-N) or $\alpha$ subunit [21]. The cytoplasmic tail of MUC1 (MUC1-CT) aids in signal transduction [17,22].

Among different types of glycosylation, O- and N-glycosylations dominate in MUC1 [23]. The MUC1-N subunit in normal cells, consists of a heavily O-glycosylated- VNTR (variable number of tandem repeat) sequence of 20-21 amino acids (PDTRPAPGSTAPPAHGVTSA), which masks the peptide core and protects it from cleavage by proteolytic enzymes, and also prevents it from undergoing clathrin-mediated endocytosis [24]. The molecular weight of MUC1 can vary between 250-500 kDa based on the percentage of glycosylation (in the range of 50-90\% of its molecular mass) and the number of tandem repeats [25]. N-glycosylation of MUC1 occurs at five potential sites, one in the ECD of MUC1-CD, and four in the degenerate repeat of MUC1-N [8]. N-glycosylation patterns are important 
for MUC1 folding, sorting, apical expression and secretion, whereas O-glycosylation is crucial for its biological properties [26,27].

MUC1 glycosylation depends on the tissue of origin and is regulated by a large number of glycosyltransferases. O-glycosylation is initiated by adding N-acetyl-galactosamine (GalNAc) to the VNTR region highly rich in threonine (Thr) and serine (Ser) residues. Following that, a large family of up to 20 distinct polypeptide GalNAc transferases (ppGalNAc-Ts) form the initial O-linked GalNAc $\alpha$-Ser/Thr structure (Tn antigen) in the endoplasmic reticulum (ER) and ER-Golgi compartments. This forms the initial O-linked GalNAc $\alpha$-Ser/Thr structure (Tn antigen) [28]. Following the formation of Tn antigen, GalNAc residue can be further modified by various distinct glycosyltransferases and construct different glycan structures of core 1 also known as T or TF (Thompson-Friedenreich) antigen (by addition of Gal residue) and core 3 (by adding GlcNAc $\beta 1-3$ GalNAc $\alpha$ ) and Sialyl-Tn antigen (STn, by addition of sialic acid residue). Glycosylation continues by extension and chain termination by the addition of carbohydrates such as sialic acid [28-30].

However, in cancer cells, MUC1 mostly displays hypoglycosylation of the core glycans, like sialyation of $\mathrm{Tn}$ and $\mathrm{T}$ antigens via sialyltransferase enzymes that lead to premature chain termination [30-34]. MUC1 expression has been shown to be up to 10 times higher in many human carcinomas than in normal tissues, which provides resistance to chemotherapy [34-36]. Therefore, antibodies against tumor associated MUC1 are more likely to bind to the antigen on the surface of tumor cells and not MUC1 on the surface of normal cells. This makes tMUC1 a top molecular target to both detect cancers as well as design antibodies against the altered glycopeptide epitopes in the TR domain. These antibodies are also used to design human T cells to target $\mathrm{tMUC1}$, called Chimeric Antigen Receptor T-cells (CAR T cells) [37-39].

\subsection{Role in GI Tumors}

MUC1 is overexpressed and aberrantly glycosylated in most human epithelial cancers [40]. The aberrantly glycosylated MUC1 expressed on malignant cells, called the tumor associated MUC1 or tMUC1 renders usually inaccessible MUC1 epitopes open to detection. MUC1 has been a molecule of interest for immunotherapy for a long time. It is a highly overexpressed cell surface antigen and has altered glycosylation in tumors [41]. However, MUC1 has been shown to play a paradoxical role following infections, acting as an anti-inflammatory molecule in healthy cells and as a pro-inflammatory molecule in cancer cells [42]. In 2009, the National Cancer Institute (NCI) had ranked tMUC1 as the second most targetable antigen out of 75 for developing cancer vaccines [43].

MUC1 has been reported to play a role in tumorigenesis by inhibition of cell death and promotion of metastasis [44-46]. MUC1 induces signaling through its cytoplasmic domain (MUC1-CT) and binds to the EGFR family of growth factor tyrosine kinases and enhances signaling through ERK activation and cell proliferation [47]. MUC1-CT interacts with $\beta$-catenin, stabilizes it and co-activates Wnt signaling [48]. MUC1 overexpression and its interactions with $\mathrm{p} 53$ and $\mathrm{FO} \times \mathrm{O} 3 \mathrm{a}$ transcription factor dampen drug-induced apoptosis and resist oxidative cell damage [49,50]. MUC1 also reduces pro-apoptotic signaling via the heat shock protein (HSP) 90, PI3K/Akt and Caspase-8 pathways [45,51,52]. An increase in depolarized MUC1 leads to the disruption of the normal cell-cell and cell-matrix adhesion and increase in cell-endothelial adhesion, allowing increased metastasis in preclinical models [53]. The hypoglycosylated tMUC1 has increased interaction with cell adhesion molecules ICAM-1 and E-selectin, both of which can improve cellular migration and vascular invasion [54]. MUC1 confers drug resistance in pancreatic ductal adenocarcinoma cells by upregulating multidrug resistance genes [55]. MUC1 has also been reported to increase metastasis through the induction of platelet-derived growth factor (PDGF-A) expression by hypoxia inducible factor (HIF)1- $\alpha$ [56] and leads to epithelial-to-mesenchymal transition in pancreatic cancer $[57,58]$. MUC1 has also been shown to regulate function of transforming growth factor- $\beta$ (TGF- $\beta$ ) and switch it from a tumor suppressor to a tumor promoter in PDA cells $[59,60]$. MUC1 is a prognostic factor that marks poor outcome in gastric cancer patients [61]. Expression of MUC1 has also been reported to be significantly correlated to metastasis in colorectal cancer [44]. 
Overexpression in multiple epithelial tumors, expression all over the surface of a tumor cell due to loss of apicobasal polarity in cancer cells, thus making it accessible to antibodies and tumor-specific aberrant glycosylation with truncated carbohydrate antigens Tn and TF in the VNTR region are features that make MUC1 an attractive target for immunotherapy [37]. Various preclinical and clinical trials have been performed in GI cancers with antibodies against different MUC1 domains (MUC1-N, SEA and MUC1-C), some of them targeting specific hallmarks of cancer (Figure 1).

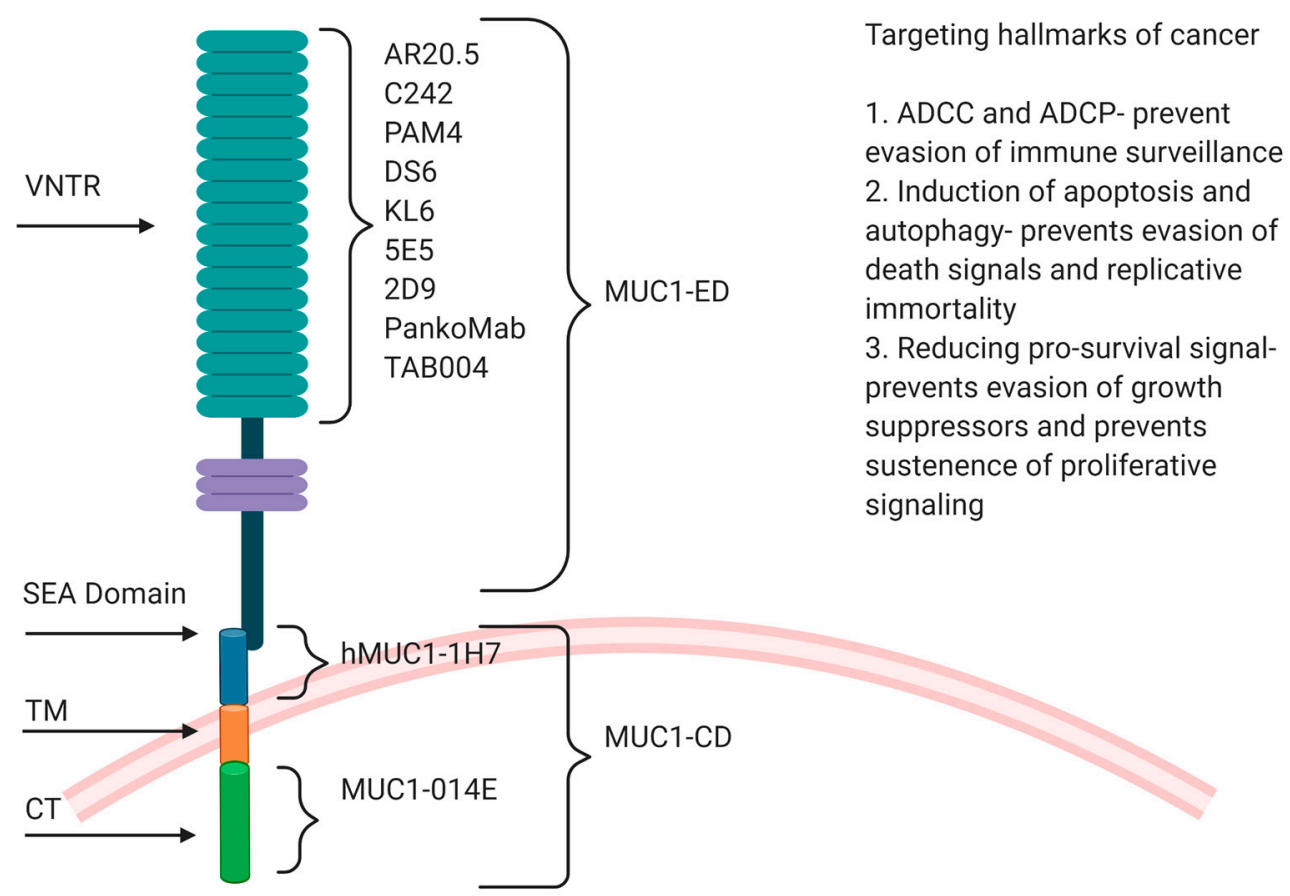

Figure 1. A schematic diagram showing the different antibodies recognizing different domains of MUC1 and also the hallmarks of cancer that they target. The various domains of MUC1 are denoted with different colors, ED and VNTR in sea green, SEA domain in blue, transmembrane domain in orange, and CT in light green.

The objective of this review is to highlight the recent advances made in the treatment of gastrointestinal cancers utilizing antibodies, immunoconjugates and antibody-derived molecular therapies against tMUC1. We have also provided perspectives on how different anti-MUC1 antibodies target different hallmarks of cancer and thus can be utilized as a combination therapy to have better clinical outcomes.

\section{Anti-MUC1 Antibodies in Preclinical and Clinical Trials}

Antibody-based immunotherapy has been used for cancer treatment for the past two decades and is one of the most effective ways to treat hematological malignancies and solid tumors [62,63]. Monoclonal antibodies (mAbs) can be generated by immunizing immunocompetent mice with tumor antigens or tumor cell lysates, or synthetically engineered to bind to specific proteins on cancer cells $[64,65]$. The fundamental mechanism of therapeutic mAbs are to tag cancer cells for phagocytosis by macrophages or killing by NK or effector T-cells, block the downstream signaling of the target molecule, induce programmed cell death (or autophagy) in the antigen expressing cancer cell, and aid in targeted delivery of therapeutic agents to specifically destroy cancer cells [64-66].

Many anti-MUC1 antibodies are in clinical trials or under pre-clinical or experimental studies. The anti-MUC1 antibody-based therapeutics developed against GI cancers that are in pre-clinical and clinical trials have been summarized in Tables 1 and 2 respectively. 
Table 1. MUC1 antibodies under preclinical trials for GI cancers.

\begin{tabular}{|c|c|c|c|c|c|c|}
\hline Antibody & Epitope & Original Antigen & Treatment under Trial & GI Cancer Type & Year & Reference \\
\hline KL-6 & $\begin{array}{l}\text { a sialylated sugar of Krebs von den Lugen-6 } \\
\text { (KL-6) PDTRPAP sequence }\end{array}$ & $\begin{array}{l}\text { a sialylated sugar of Krebs von } \\
\text { den Lugen-6 (KL-6) PDTRPAP } \\
\text { sequence }\end{array}$ & $\begin{array}{l}\text { 99mTc labeled } \\
\text { anti-KL-6/MUC1 }\end{array}$ & Pancreatic Cancer & 2008 & [67-69] \\
\hline MY.1E12 & $\begin{array}{l}\text { sialyla2-3galactosylh1-3Nacetylgalactosaminide } \\
\text { linked to a distinct threonine } \\
\text { residue in the MUC1 tandem repeat }\end{array}$ & HMFG & $\begin{array}{l}\text { 3-ICG-acyl-1,3-thiazolidine-2-thione } \\
\text { labeled MY.1E12 }\end{array}$ & Gastric Cancer & 2008 & [70-73] \\
\hline $5 \mathrm{E} 5,2 \mathrm{D} 9$ & Tn or STn in the tandem repeat domain & $\begin{array}{c}\text { GalNAc-glycosylated MUC1 } \\
\text { glycopeptide } \\
\text { (VTSAPDTRPAPGSTAPPAHG) } \\
\text { conjugated to KLH }\end{array}$ & 5E5 MUC1-CAR-T cells & Pancreatic Cancer & $\begin{array}{l}2016 \\
2019\end{array}$ & [74] \\
\hline hMUC1-1H7 & $\begin{array}{l}\text { extracellular domain of MUC1 C-terminal subunit } \\
\text { (MUC1-C) }\end{array}$ & $\begin{array}{l}\text { recombinant human }(\mathrm{rh}) \text { protein } \\
\text { including extracellular region of } \\
\text { MUC1- } \\
\text { C (rhMUC1-EC192) obtained } \\
\text { from MCF7 cells }\end{array}$ & hMUC1-1H7 & Pancreatic Cancer & 2004 & {$[75,76]$} \\
\hline TAB004 & STAPPVHNV within the TR sequence & $\begin{array}{c}\text { Protein lysate from } \\
\text { MUC1-expressing tumors that } \\
\text { developed in a MUC1 } \\
\text { transgenic mice (PDA mice) that } \\
\text { expressed human MUC1 }\end{array}$ & $\begin{array}{l}\text { (1) TAB } 004 \\
\text { (2) CAR-T cell therapy } \\
\text { (3) Bispecific antibody } \\
\text { with anti-CD3 }\end{array}$ & Pancreatic Cancer & \multicolumn{2}{|c|}{$2008-2019$ [77-82] } \\
\hline
\end{tabular}


Table 2. MUC1 antibodies under clinical trials for GI cancers

\begin{tabular}{|c|c|c|c|c|c|c|c|c|c|c|}
\hline Antibody & Epitope & Original Antigen & & Treatment under Trial & & GI Cancer Type & & Clinical Trial Status & Year & Reference \\
\hline huC242 & $\begin{array}{l}\text { Sialyl-Lewis a epitope CanAg } \\
\text { glycoprotein which is similar to MUC1 }\end{array}$ & $\begin{array}{l}\text { Human colorectal } \\
\text { adenocarcinoma cell line } \\
\text { COLO205 }\end{array}$ & & huC242-DM4 & $\begin{array}{l}\text { (1) } \\
\text { (2) }\end{array}$ & $\begin{array}{l}\text { Non-colorectal Cancer, } \\
\text { Pancreatic Cancer } \\
\text { Locally Advanced and } \\
\text { metastatic Stomach, Gastric } \\
\text { and other GI cancers }\end{array}$ & $\begin{array}{l}(1) \\
(2)\end{array}$ & $\begin{array}{l}\text { Phase I completed } \\
\text { Phase II withdrawn }\end{array}$ & $\begin{array}{l}2006 \\
2008\end{array}$ & [83-88] \\
\hline huPAM4 & $\begin{array}{l}\text { Domain located between the amino } \\
\text { terminus and start of the repeat domain } \\
\text { of a MUC1 antigen (non- VNTR) and } \\
\text { also react with MUC5AC }\end{array}$ & $\begin{array}{l}\text { Mucin purified from the } \\
\text { xenografted RIP I human } \\
\text { pancreatic carcinoma }\end{array}$ & & 111In-huPAM4 & & Pancreatic Cancer & & Phase I terminated & 2006 & [89-91] \\
\hline $\begin{array}{c}\text { hPAM4 } \\
\text { (Clivatuzumab) }\end{array}$ & $\begin{array}{l}\text { Domain located between the amino } \\
\text { terminus and start of the repeat domain } \\
\text { of a MUC1 antigen (non-VNTR) and also } \\
\text { react with MUC5AC }\end{array}$ & $\begin{array}{l}\text { Mucin purified from the } \\
\text { xenografted RIP I human } \\
\text { pancreatic carcinoma }\end{array}$ & $\begin{array}{l}(1) \\
(2)\end{array}$ & $\begin{array}{l}\text { 90Y-hPAM4 (Clivatuzumab) } \\
\text { 90Y-hPAM4-Tetraxetan \& } \\
\text { Gemcitabine vs. Placebo } \\
\text { \& Gemcitabine }\end{array}$ & $\begin{array}{l}(1) \\
(2)\end{array}$ & $\begin{array}{l}\text { Pancreatic Cancer } \\
\text { Metastatic } \\
\text { Pancreatic Cancer }\end{array}$ & (2) & $\begin{array}{l}\text { Phases I and } \\
\text { II completed } \\
\text { Phase III terminated }\end{array}$ & $\begin{array}{l}2008 \\
2013\end{array}$ & {$[92,93]$} \\
\hline $\begin{array}{c}\text { SAR56665 } \\
\text { 8huDS6-DM4 }\end{array}$ & $\begin{array}{l}\text { O-linked glycans with } \alpha 2,3 \text {-sialylated } \\
\text { and } \beta 1,4 \text {-galactosylated termini in VNTR }\end{array}$ & $\begin{array}{l}\text { Human serous ovarian } \\
\text { carcinoma }\end{array}$ & & $\begin{array}{c}\text { SAR56665 } \\
\text { 8huDS6-DM4 }\end{array}$ & & Pancreas & & Phase II completed & 2010 & \\
\hline $\begin{array}{l}\text { PankoMab-GEX'M } \\
\text { (Gatipotuzumab) }\end{array}$ & $\begin{array}{l}\text { Epitope...PDT*RP..., where } \mathrm{T}^{*} \text { is } \\
\text { O-glycosylated with GalNAca1- or a } \\
\text { similar } \\
\text { short, non-sialylated glycan such as } \\
\text { Galb1-3GalNAca1-(core-1) }\end{array}$ & $\begin{array}{l}\text { Tumor MUC1 from a } \\
\text { desialylated human breast } \\
\text { cancer source }\end{array}$ & $\begin{array}{l}\text { (1) } \\
\text { (2) }\end{array}$ & $\begin{array}{l}\text { PankoMab-GEXTM } \\
\text { (Gatipotuzumab) } \\
\text { Combination of } \\
\text { Gatipotuzumab and } \\
\text { anti-EGFR Tomuzotuximab }\end{array}$ & $\begin{array}{l}(1) \\
(2)\end{array}$ & $\begin{array}{l}\text { Pancreatic } \\
\text { Colorectal }\end{array}$ & $\begin{array}{l}(1) \\
(2)\end{array}$ & $\begin{array}{l}\text { Phase II, ongoing } \\
\text { Recruiting for Phase I }\end{array}$ & $\begin{array}{l}2010 \\
2017\end{array}$ & [94-97] \\
\hline $\begin{array}{l}\text { PD-1 inhibitor } \\
\text { armed with an } \\
\text { anti-MUC } 1 \text { and } \\
\text { anti- CD3 } \\
\text { bispecific antibody }\end{array}$ & Information unavailable & Information unavailable & & $\begin{array}{l}\text { PD- } 1 \text { inhibitor armed with an } \\
\text { anti-MUC } 1 \text { and anti- CD3 } \\
\text { bispecific antibody }\end{array}$ & & $\begin{array}{l}\text { Advanced Gastric, Colorectal, } \\
\text { Pancreatic and Liver cancers }\end{array}$ & & Recruiting for Phase II & 2018 & [98] \\
\hline AR20.5 & DTRPAP and DTnRPAP & $\begin{array}{l}\text { MUC1 from an ovarian cancer } \\
\text { patient, derived from human } \\
\text { fluids and breast cancer cell } \\
\text { MCF-7 culture medium }\end{array}$ & $\begin{array}{l}(1) \\
\text { (2) }\end{array}$ & $\begin{array}{l}\text { AR20.5 } \\
\text { Combination of mAb-AR20.5, } \\
\text { anti-PD-L1 and Poly ICLC }\end{array}$ & $\begin{array}{l}(1) \\
(2)\end{array}$ & $\begin{array}{l}\text { Advanced adenocarcinoma } \\
\text { Pancreatic Cancer }\end{array}$ & $\begin{array}{l}(1) \\
(2)\end{array}$ & $\begin{array}{l}\text { Completed Phase I } \\
\text { Phase I/II ongoing }\end{array}$ & $\begin{array}{l}2004 \\
2018\end{array}$ & {$[24,99,100]$} \\
\hline
\end{tabular}




\subsection{Monoclonal Antibodies}

\subsubsection{Antibodies Recognizing Non-Glycopeptide Epitope}

Human milk fat globule 1 (HMFG1) is an IgG1 murine antibody with kappa light chain, recognizing PDTR epitope within the VNTR region of MUC1-ED. The humanized HMFG1 (AS1402, huHMFG1, Therex, BTH-1704, R-1550) was generated by transferring the complementarity determining regions (CDRs) of the murine HMFG1 onto selected human framework with the same affinity to MUC1 [101,102]. To directly target MUC1 positive advanced pancreatic tumors and trigger neutrophil-mediated immune response, the binding capacity of this $\mathrm{mAb}$ in combination with a polysaccharide beta 1,3/1,6 glucan (derived from S.cerevisiae) as an immune stimulator with two drugs gemcitabine and Imprime PGG was evaluated [103]. The secondary objectives were to characterize the adverse effects, time to progression, clinical response, progression-free and overall survival. However, this phase Ib trial (NCT02132403) was terminated due to drug recall.

PAM4 is another $\operatorname{lgG} 1$ murine $\mathrm{mAb}$, generated by immunizing mice with mucin purified from the xenografted RIP I human pancreatic carcinoma [91]. This mAb can recognize $85 \%$ of the pancreatic carcinomas and $50 \%$ of the colon carcinomas. However, it does not detect breast, ovarian, renal, prostate and liver cancers [90]. It has been reported that PAM4 is not related to the core epitopes of VNTR and that it also binds to other mucin proteins like MUC5AC [91,104]. In the preclinical studies, 131I- and 90Y-labeled PAM4, was shown to control pancreatic cancer with enhanced survival and clinical responses in pancreatic cancer patients [89,90]. In the phase I clinical trial, 131I-PAM4 IgG and 99mTc-PAM4 Fab' showed the specific tumor localization in four out of five patients, therefore ensuring these are ideal candidates for further trials [90,105]. Humanized PAM4 (hPAM4, IMMU-107) also known as clivatuzumab was constructed and radiolabeled with Yttrium (90Y) and used for patients with stage III and IV of pancreatic cancer. In a phase I trial, it was shown that 90Y-Clivatuzumab tetraxetan was well tolerated with toxicity restricted to the bone marrow and manageable hematologic toxicity was seen at the maximal tolerated dose of 90Y. Tumor targeting was observed in most patients by using 111In-labeled antibody, and even with mucin antigen present in the serum, there were apparently no issues with the biodistribution or clearance of the antibody. All patients demonstrated disease progression at or after week eight, and some of them had stable target lesions at four weeks after treatment [92]. Hence, combination of chemotherapy and radioimmunotherapy agents was considered for future trials.

Phase I/II trials with 80 participants are ongoing (NCT00603863) to test whether different doses of 90Y-hPAM4 in combination with gemcitabine are safe to give in patients with previously untreated pancreatic cancer. Clinical efficacy of Y-clivatuzumab tetraxetan (DOTA) with or without low-dose gemcitabine (PANCRIT ${ }^{\circledR}-1$ ) was assessed in a phase I/II/III trial with metastatic pancreatic cancer patients which appeared to be an active first-line therapy for pancreatic cancer [93], but eventually, it was discontinued due to insufficient improvement in overall survival in comparison to placebo [NCT01956812].

GP1.4 is an anti-MUC1 antibody that caused internalization of EGFR in pancreatic cancer cells. This inhibited ERK phosphorylation by EGF stimulation in a MUC1 dependent manner. Inhibition of ERK phosphorylation by GP1.4 resulted in the suppression of proliferation and migration of pancreatic cancer cells [106].

TAB004 is a murine IgG1 mAb that was initially developed by immunizing Balb/c mice with lysates from MUC1-expressing tumors that developed in a human tMUC1 bearing transgenic mouse [77]. TAB004 targets the epitope area with sequence STAPPVHNV present within the TR sequence (AA950-958) of hypoglycosylated tMUC1 [13,17,78,107]. TAB004 distinguishes between normal and tumor-associated forms of MUC1 solely based on the expression of hypo-glycosylated or aberrantly glycosylated MUC1. TAB004 alone or in conjugation with dye-doped mesoporous silica nanoparticles was used to detect breast cancer in vivo $[80,108]$. TAB004 was also shown to be a diagnostic marker for cancer stem cells and circulating MUC1 in mice and patients with pancreatic 
cancer [109]. TAB004 in combination with IL2 was shown to improve survival in PDA models by the following mechanisms: (1) reduction in tumor-induced immune regulation and (2) increasing recruitment of CD45+CD11b+ cells, thus increasing antibody-dependent-cellular-cytotoxicity or antibody-dependent-cellular-phagocytosis (ADCC/ADCP) [79]. It has also been reported that, the TAB004 antibody induces complement-independent growth inhibitory effect on PDA cells and significantly increases the anti-tumor efficacy of chemotherapy drugs like 5-FU, Gemcitabine and Paclitaxel [81]. In another study, humanized TAB004 was conjugated to ${ }^{111}$ In and ${ }^{225}$ Ac-DOTA and this immunoconjugate not only could target the tumor specifically but also showed complete preclinical response in triple negative breast cancer [110].

MUC1-014E is another anti-MUC1 antibody raised against an intracellular nonrepeating 19-amino-acid sequence (RYVPPSSTDRSPYEKVSAG) of the MUC1-CT, using a synthetic peptide with the 7-amino-acid epitope (STDRSPY). MUC1-014E showed sharp and specific staining of carcinoma cells, but no staining in fibroblasts, endothelial cells, and inflammatory cells. High rates of positive immunohistochemical staining (97-100\%) was found in 107 gastrectomy specimens compared with the other MUC1-related antibodies (MUC1-DF3, MUC1-Ab-5 and PAb anti-MUC1*1110-ecd). MUC1-014E also recognized isolated cancer cells of signet-ring cell carcinoma (sig) and non-solid type poorly differentiated stomach adenocarcinoma (por2). Therefore, this mAb could be used to detect cells in scirrhous gastric cancer [111].

hMUC1-1H7 is an anti-hMUC1 murine mAb developed against a recombinant MUC1 obtained from the breast cancer cell MCF7. It significantly reduced proliferation of breast cancer cells in which it is internalized and specifically localized in MUC1-expressing tumors in the xenograft mouse models. hMUC1-1H7 is specific for the extracellular domain of MUC1-CD and can bind to shed MUC1 as well [76]. It has also been reported that, G3 can inhibit EGF-mediated ERK phosphorylation and cyclin D1 expression, thus, inhibiting EGFR signaling pathways in pancreatic cancer models [75].

\subsubsection{Antibodies Recognizing Glycopeptide Epitopes}

PankoMab is a murine IgG1, kappa light chain mAb recognizing tMUC1 glycopeptide. It has shown a reduced rate of binding to circulating tMUC1 and mononucleated cells in the serum of colon and pancreatic cancer patients [94]. There are various chimeric and humanized formats of PankoMab under clinical trials as suitable candidates for therapeutic and diagnostic applications [95]. PankoMab-GEX ${ }^{\mathrm{TM}}$ (PMG) also known as Gatipotuzumab (previously known as PankoMab-GEX ${ }^{\mathrm{TM}}$ ), is a glyco-optimised $\mathrm{mAb}$ with many advantages. For example, it has higher tumor specificity and affinity with an increased number of binding sites, reduced binding to shed MUC1 from colon and pancreatic carcinoma, no binding to peripheral blood mononucleated cells, stronger ADCC, and rapid internalization compared to other antibodies [95]. Its mechanisms of action include ADCC and ADCP. A phase I study in patients with tMUC1 positive advanced solid tumor showed that PMG was safe, well tolerated and showed promising anti-tumor activity [96]. The phase 2 study evaluated the efficacy and safety of PMG's maintenance therapy compared to placebo in patients with recurrent ovarian, fallopian tube or primary serous peritoneal cancer [97]. This randomized double blinded study reported that PMG failed to improve the time without disease recurrence when given as a single entity [97]. However, it showed a good safety profile, hence, targeting tMUC1 by this antibody in combination with other standard chemotherapy or developing a bi-specific antibody to modulate the immune system holds promise to improve its anti-tumor efficacy [97].

AR20.5 (BrevaRex) is a murine monoclonal antibody (IgG1) developed by immunizing mice with three different sources including MUC1 derived from an ovarian cancer patient, human fluids and MCF-7 cell culture medium. It reacts with six amino acids within the VNTR region (DTRPAP). However, addition of a single GalNAc enhanced the binding affinity of AR20.5 to the MUC1 epitope [24]. AR20.5 forms a complex with circulating MUC1 and/or transmembrane MUC1 on tumor cells. This complex can be internalized by dendritic cells which facilitates effective antigen-processing and cross-presentation of MUC1 to T cells, and leads to the activation of cytotoxic T cells to kill the tumor [112]. In the phase I trial 
of AR20.5 patients with advanced adenocarcinoma were treated, it induced MUC1-specific immune responses, did not have dose-limiting toxicity, and induced no hypersensitivity reactions. The 2-mg dose showed the strongest biological activity, and was evaluated in future trials [100]. The combination of AR20.5, anti-PD-L1 antibody and PolyICLC rejected human MUC1 expressing tumors and provided a long-lasting, MUC1-specific cellular immune response, which when adoptively transferred to human MUC1 transgenic (MUC.Tg) mice, provided protection against tumor formation. CD8+ cells were found to be the effectors for the MUC1-specific immune response generated by this combination. In the US, a phase I/II clinical trial is ongoing for pancreatic cancer by OncoVent Co., Ltd., with this combination [99].

The DS6 antibody is an IgG1 murine antibody recognizing the CA6 sialoglycotope of $\mathrm{tMUC1}$ that is overexpressed in a variety of solid tumors, including ovarian, breast, cervical, pancreatic and lung cancers. DS6 detects a CA6 antigen that is different from well-characterized tumor-associated antigens, such as MUC1, CA125 and the histo-blood group-related antigens sLea, sLex and sTn [113]. DS6 specifically binds to the tandem repeat domain of CA6-positive MUC1 based on the presence of mucin type O-linked glycans with $\alpha 2,3$-sialylated and $\beta 1,4$-galactosylated termini [114]. Humanized DS6 (huDS6) antibody was conjugated to the cytotoxic maytansinoid derivative drug DM4 through a cleavable linker. The ADC was called SAR566658 and it showed antitumor efficacy against CA6-positive human pancreas, cervix, bladder, and ovary in vivo tumor xenograft models, with a minimal effective dose correlating with CA6 expression as well as better efficacy than standard-of-care nontargeted tubulin binders. SAR566658 was used in a phase I clinical trial with 114 patients with refractory solid tumors. It showed a satisfactory safety profile and antitumor activity. Tumor improvement was shown in 35-60\% of patients at different dosages of SAR566658 [115].

The monoclonal IgG1-kappa antibody C242 was developed by immunizing a mouse with human colorectal adenocarcinoma cell line COLO205. Humanized C242 (HuC242 or Cantuzumab) has the CA242 epitope and reacts with a novel glycoform of MUC1 also known as CanAg glycoprotein (cancer antigen) [83]. CanAg is very highly glycosylated, rich in fucose and sialic acid and $\mathrm{Hx}-\mathrm{CanAg}$ (heavy subunit) is very similar to MUC1 in amino acid composition, but L-CanAg (light subunit) is different. Deglycosylated H-CanAg can be recognized by the monoclonal antibodies SM-3 and HMFG-2 [84]. Also, due to its high expression in most pancreatic, biliary and colorectal cancers, CanAg is a potential candidate for $\mathrm{mAb}$-based therapies. In a phase I trial, Cantuzumab was conjugated to an anti-microtubule agent mertansine (DM1) and different doses were used to treat colon and rectum carcinomas or other malignancies with positive CanAg antigen as a single intravenous infusion. Results showed that HuC242-DM1 is safe and well tolerated with effective antitumor activity [85,86]. In another phase I trial, cantuzumab conjugated to potent cytotoxic maytansinoid drug ravtansine (DM4), called IMGN242, was found to be well tolerated in colorectal and pancreatic cancer patients at $168 \mathrm{mg} / \mathrm{m}^{2}$ dose. This provided a basis to perform phase II clinical studies [87]. The phase II trial was started in CanAg-expressing gastric cancer patients at a dose of $168 \mathrm{mg} / \mathrm{m}^{2}$. The data has been amended to differentiate the administered dose of IMGN242 based on the patient's plasma CanAg levels [88].

KL-6 is a mouse IgG1 mAb that specifically recognizes a sialylated sugar of Krebs von den Lugen-6 (KL-6), which is considered a MUC1-derived glycoprotein antigen. The minimal antigenic epitope for binding of this antibody is PDTRPAP. It has been reported that anti-KL-6/MUC1 mAb increased aggregation of MUC1 glycoproteins at one pole of the cell, called capping of MUC1 on the surface and facilitated E-cadherin-mediated cell-cell interaction in breast cancer cell lines YMB-S and ZR-75-1S. Anti-KL-6 also enhanced the cytotoxic activity of lymphokine-activated killer (LAK) cells. The mechanism of action of this antibody is capping of MUC1 and restoring cell-cell adhesion by E-cadherin, which induces cell cycle arrest by upregulation of the cyclin-dependent kinase, p27 [116]. This also leads to increased accessibility for effector cells to kill tumor cells [67-69]. 99mTc labeled anti-KL-6/MUC1 antibody was shown to be a tumor-specific radiotracer that detects pancreatic cancer in vivo, but no further information is available [117]. 
MY.1E12 is another murine anti-human MUC1 mAb that binds to MUC1 bearing sialylated O-linked oligosaccharides. MY.1E12 was generated by immunizing mice with HMFG. It can identify colon carcinoma tissue $[70,71]$. MY.1E12 specifically reacts to T structure (ST) attached to Thr8. The sialylation of the T structure (ST) enhances its reactivity with MUC1 [72]. ICG-N-hydroxysulfosuccinimide ester (ICG-sulfo-OSu) and 3-ICG-acyl-1,3-thiazolidine-2-thione (ICG-ATT) were developed as infrared fluorescent-labeling reagents, and anti-human CEA antibody and FMY.1E12 were labelled with 3-ICG-acyl-1,3-thiazolidine-2-thione. This was shown to recognize the gastric cancer tissue specimens with a strong fluorescent signal [73].

5E5 and 2D9 are mouse IgG1k mAbs that were generated by immunization of wild-type Balb/c mice with GalNAc-glycosylated MUC1 glycopeptide (VTSAPDTRPAPGSTAPPAHG) conjugated to KLH. These antibodies exhibited high selectivity for MUC1 tandem repeat glycopeptides with Tn and STn O-glycans and showed preference for Tn-MUC1 glycoforms that had the highest O-glycan occupancy. They can bind to MUC1 with Tn or STn in the GSTA sequence of tandem repeats but do not bind to the GSTA epitope carrying T [74].

\subsection{Bispecific Antibodies for MUC1}

Bispecific antibodies (bsAbs) can recognize two distinct epitopes or antigens simultaneously and therefore enhance the ability of immune cells to engage to tumor cells. Recently, MUC1 has been considered for designing bsAbs.

MUC1-CD16-Bi antibody is a novel bispecific antibody generated via a Serine-Glycine linkage between single domain antibodies (VHH segments) against tMUC1, and CD16 presented on natural killer (NK) cells. The bsAb against MUC1 named MUC1-Bi-1 was humanized by grafting the CDRs of both segments to DP-47 V-segment. Both MUC1-Bi-1 and its humanized version specifically detected tMUC1 on several cancer cell lines (SKOV3, HT29, and LS174) and potentially introduced them to NK cells. These bsAbs had no binding affinity and cytotoxicity to MUC1 negative CHO and HepG2 cells even in the presence of NK cells [118,119].

Different types of bsAbs were constructed with binding affinity to both tMUC1 and CD3 on T-cells. Fab'-S-NB fragments of OKT-3 mAb (anti-CD3) and Fab-SH fragments of MUSE11 mAb (anti-tMUC1) were used to generate the first bsAb which increased the antitumor activity of CD3+ T-LAK cells. MUSE11 is a mouse IgG1 mAb developed against the ascites fluid of gastric cancer patients. The epitope of this antibody could be within the amino acid sequence PDTRPAPG of tMUC1 [120]. MUC1 × CD3 BsAb was constructed with MUSE11 (anti tMUC1) and OKT-3 (anti-CD3), and MUC1 $\times$ CD2S BsAb was constructed with MUSE11 and 15E8 (anti-CD28) antibodies. The Fab'-SH from MUSE11 and Fab-S-NB of mouse IgG1 15E8 (anti-CD28) antibodies were used. These BsAbs showed growth inhibition of TFK-1 cancer cells and bile duct carcinoma in SCID mice [121]. The BsAbs (MUC1 × CD3 BsAb and MUC1 $\times$ CD28 BsAb) together exhibited 60\% cytotoxicity in vitro, similar to that shown by BsAb $(\mathrm{MUC1} \times \mathrm{CD} 3)$ alone. Although reduction in tumor growth was limited, simultaneous administration of a combination of three bsAbs $(\mathrm{M} \times 3, \mathrm{M} \times 28$ and $\mathrm{M} \times 2 \mathrm{bsAb})$ with peripheral blood mononuclear cells (PBMCs) or T-LAK cells in vitro showed higher cytotoxicity against MUC1-expressing bile duct carcinoma cells [121].

Mx3 diabody is a recombinant BsAb generated using the variable domains of two mAbs directed at effector cells, one against CD3 (OKT-3, mouse IgG2a) and the other against CD28 (15E8, mouse IgGl), and MUSE11 (mouse IgGl), directed at tMUC1 [122]. One chain consists of a variable heavy chain specific for MUC1 linked to a variable light chain specific for CD3 with a short polypeptide linker GlyGlyGlyGlySer (GGGGS). The second chain has a variable light chain specific for MUC1 linked to a variable heavy chain specific for CD3. Therefore, Mx3 diabody can specifically bind to both MUC1 and CD3 positive LAK cells with a T cell phenotype (T-LAK). Mx3 diabody with T-LAK showed growth inhibition in about $98 \%$ of TFK-1 cells with an effector:target ratio of 10 [122]. Mx3 was fused genetically to the mutated superantigen staphylococcal enterotoxin A (SEA) D227A to specifically target bile duct 
carcinoma (BDC). This super-antigen fused diabody also showed the potential to inhibit the BDC cell line TFK-1 and reduce tumor size when compared to the Mx3 diabody alone [123].

A bsAb containing $F\left(a b^{\prime}\right) 2 / F\left(a b^{\prime}\right)$ fragments with a functional chemical linker is the anti-MUC1/anti-Ga chelate. A mouse IgG1 12H12 mAb raised against a mouse glycosylated form of MUC1 called TAG-12 was combined to another mouse IgG3 anti-Ga chelate mAb. Prior to 3A10 F(ab') coupling, the $12 \mathrm{H} 12 \mathrm{~F}\left(\mathrm{ab}^{\prime}\right) 2$ fragment was labeled with 125I. This bispecific-mAb showed improved immunoscintigraphic tumor localization in breastcarcinoma bearing mice [124].

Another bsAb has been constructed with a novel PD-1 inhibitor-induced cytokine- induced killer cells (CIKs) armed with an anti-tMUC1 and anti- CD3 antibodies. This bsAb is currently under several phase II randomized clinical trials for advanced gastric, kidney, lung, breast, colorectal, pancreatic and liver cancers, but there is no further information available ([NCT03554395], [NCT03540199], [NCT03501056], [NCT03524261], [NCT03524274], [NCT03509298], and [NCT03484962]) [98].

\subsection{CAR-T Cells Targeting MUC1}

TAB004 has been used to make a CAR-T cell construct, which has exhibited significant cytotoxic activity against pancreatic cancer cells and reduced growth of orthotopic pancreatic tumors in a NOD-SCID mouse model [82]. Some PDA cells, for example CFPAC and HPAF II, were found to be resistant to the therapy and several genes were overexpressed in them such as indoleamine 2, 3-dioxygenases-1 (IDO1), cyclooxygenase 1 and $2(\mathrm{CO} \times 1 / 2)$, and galectin-9 (Gal-9) [82]. This study showed that combining biological inhibitors of IDO1, $\mathrm{CO} \times 1 / 2$, and Gal-9 with the CAR-T cells resulted in significant enhancement of CAR-T cell cytotoxicity against PDA cells.

$5 \mathrm{E} 5 \mathrm{mAb}$ showed high specificity to breast cancer cells and tissue $[37,123]$ and was used to develop MUC1 CAR-T cells. These CAR-T cells showed cytotoxicity against leukemia and pancreatic cancer cells and also enhanced survival of mice by eliminating the barriers for engagement of the endogenous immune system $[38,125]$.

\section{Molecular Interactions between MUC1 and Its Antibodies}

X-ray crystallography of antibody crystal structures [126] and NMR analysis of glycopeptides [127] are used to understand the biochemical interactions or molecular recognition between the antigen and antibody. The Tn antigen is one of the most important structural motifs of tMUC1 found widely in many different aggressive carcinomas $[128,129]$. It has been shown by years of extensive effort to develop antibodies targeting tMUC1 having the Tn antigen, that most anti-MUC1 antibodies do not directly bind to carbohydrates. However, the binding affinities with the immunodominant MUC1 are shown to be significantly increased by O-glycosylation in this area [130-132]. AR20.5 bound to the glycopeptide with stronger affinity than the naked peptide. These observations led to the hypothesis that the antibody must specifically bind the carbohydrate as well as the peptide. X-ray crystallography of the structures of AR20.5 [24] and SM3 [133] in complex with both peptide and glycopeptide revealed that the carbohydrate did not have any specific polar contacts with the antibody. The high affinity for the glycopeptide and the lack of specific binding contacts of AR20.5 suggest that glycosylation of MUC1 stabilizes an extended bioactive conformation of the peptide that is recognized by the antibody. Evidence suggests that glycosylation of the peptide alters the conformational equilibrium of the antigen, and this allows the antibody to select the correct conformation. Therefore, glycosylation of MUC1 is important for the generation of high affinity therapeutic antibodies [24]. The anti-MUC1 KL- 6 antibody distinguishes between the ST, Tn, and T antigens at the same O-glycosylation site independent of the modifications at other potential sites [68,131,132]. The NMR study suggests that KL6 mAb strictly recognizes the epitope from the extended trans conformation of a glycopeptide, which has been modified with the ST antigen. Detailed molecular recognition studies on MUC1 and anti-MUC1 antibodies and the use of synthetic glycopeptide library to develop a new class of antibodies targeting "dynamic glycopeptidic neoepitopes" with disease-relevant O-glycosylation in immunodominant mucin domains have been described recently [134]. 
The lack of carbohydrate-binding specificities in most anti-MUC1 mAbs is a huge challenge for the development of MUC1-based therapeutic antibodies. Antibodies binding to cancer-relevant glycopeptidic neoepitopes with higher specificities in carbohydrate recognition will be beneficial in the development of anti-MUC1 mAbs as therapeutic and diagnostic agents in the clinical settings.

\section{Concluding Remarks and Future Perspectives}

In spite of MUC1 being a top target, multiple trials with MUC1 antibodies and antibody-derived immunotherapies have failed to translate to the clinic. Most of the trials have been discontinued for not being sufficiently effective. There may be various reasons for the inefficiency of the antibodies. As of now, many anti-MUC1 antibodies have been developed against the highly immunogenic VNTR region of MUC1 $\alpha$ chain (MUC1-ED) [135]. After cleavage at the SEA domain, the MUC1-N is often shed from the surface of cells and released into the peripheral blood. The shed $\alpha$ subunits (MUC1-N) sequester anti-MUC1 antibodies against the VNTR region, preventing them from binding to the surface MUC1 [95]. To overcome this problem, antibodies against MUC1-CD could be used as a more effective strategy. Shedding of MUC1-N increases its levels in the serum of patients with various cancers [136-138], thus, reducing the specificity and effective binding of the antibodies to MUC1 on the tumor cells $[136,139]$. Therefore, serum levels of MUC1 in different cancer patients need to be evaluated to find an effective dose of the antibodies [140]. In addition, bsAbs can be made by combining immune checkpoint inhibitors such as anti-PD1 and anti-PD-L1 antibodies with anti-MUC1 antibodies. This will increase engagement of the immune cells with the tumor. In recent years, antibodies are being designed against the other domains of MUC1 including SEA, extracellular, and intracellular MUC1-CT. Therefore, rational designing of antibodies and combination therapy strategies are important to achieve a good safety and efficacy profile against MUC1 expressing cancers.

Antibodies to the non-glycopeptide part of the VNTR region have not been able to generate an effective cellular or humoral immune response to tMUC1 [141]. Antibodies to MUC1 peptide also do not effectively recognize MUC1-expressing tumor cells. However, antibodies raised against shortened glycopeptide structures with a simple T antigen ( $\mathrm{T}$, Gal $\beta 1-3 \mathrm{GalNAc}$ ), sialyl Tn (NeuAc $\alpha 2-6 \mathrm{GalNAc})$ and $\operatorname{Tn}$ (GalNAc) elicit the strongest immune response against MUC1-expressing tumor cells [142]. This happens due to the specific presence of Tn and STn glycans on MUC1 expressing cancer cells, but not on normal epithelial cells and the blocked regions of the VNTR domain get exposed to recognition by antibodies, thereby, producing tumor-specific recognition sites. As evident, studying the glycosylation changes have led to the development of potentially effective MUC1-based immunotherapy [143,144]. Some anti-MUC1 antibodies can recognize the MUC1 epitopes on both normal epithelial and tumor cells thus compromising the specificity [145]. Also, heterogeneity of MUC1 expression levels, the glycosylation pattern and subcellular distribution contribute to reduced binding efficiency. The different glycoforms may confer an evolutionary advantage on the tumor cells to be resistant against antibody-based therapies $[145,146]$. Therefore, a combination of antibodies that can detect many glycoforms of MUC1 can be considered for clinical trials.

Anti-MUC1 antibodies directed against the SEA domain target the junction of MUC1 $\alpha$ and $\beta$ subunits, which is composed of intact epitopes from both $[147,148]$. These anti-SEA domain antibodies have shown high affinity and effectivity compared to antibodies targeting the VNTR region [148].

The mechanism of action anti-MUC1 mAbs target one or more hallmarks of cancer. For example, some antibodies have been reported to show ADCC and ADCP, some others block anti-apoptotic mechanisms thus inducing cell death, also some antibodies reduce expression of pro-survival genes. Gatipotuzumab is a glycooptimized antibody developed by Glycotope's GlycoExpress ${ }^{\mathrm{TM}}$ platform that significantly improved treatment outcome with mechanisms such ADCC, tumor cell phagocytosis and induction of apoptosis compared to non-glycooptimized biotherapeutics [97]. Other antibodies against MUC1 glycopeptide, such as 5E5 and 1B2, have been shown to be effective as immunotherapy strategies because of their high specificity to tMUC1 and ability to induce ADCC [149]. Therefore, by utilizing the mechanism of action of an antibody, strategies could be developed to eliminate the tumor. 
However, a decrease in concentration of anti-MUC1 antibodies targeting the tumor and their poor internalization due to the extracellular MUC1-N barrier remain major hurdles. To overcome this, development of antibody fragments can be considered [143,150]. Also, a whole or fragmented antibody could be conjugated to potent drugs to target specific types of tumor cells. For example, Napabucasin, which is a STAT-3 inhibitor was under Phase III clinical trials for PDA but was discontinued due to futility [151]. However, it has been shown that high-MUC1 PDA cells are more sensitive toward the STAT-3 inhibitor Napabucasin [152]. Therefore, anti-MUC1 antibodies armed with Napabucasin may be a promising strategy to eliminate high-MUC1 tumors. Bispecific and trispecific antibodies armed with anti-PD-1, anti-MUC1 and anti-CD3 are new products under clinical trials [98].

Author Contributions: M.B. and P.M. conceived the idea and prepared the manuscript. All authors have read and agreed to the published version of the manuscript.

Funding: This research received no external funding.

Conflicts of Interest: The authors declare no Conflict of Interest.

\section{References}

1. Bray, F.; Ferlay, J.; Soerjomataram, I.; Siegel, R.L.; Torre, L.A.; Jemal, A. Global cancer statistics 2018: GLOBOCAN estimates of incidence and mortality worldwide for 36 cancers in 185 countries. CA A Cancer J. Clin. 2018, 68, 394-424. [CrossRef] [PubMed]

2. Yang, S.; Wu, S.; Huang, Y.; Shao, Y.; Chen, X.Y.; Xian, L.; Zheng, J.; Wen, Y.; Chen, X.; Li, H. Screening for oesophageal cancer. Cochrane Database Syst. Rev. 2012, CD007883. [CrossRef] [PubMed]

3. Bjelakovic, G.; Nikolova, D.; Simonetti, R.G.; Gluud, C. Antioxidant supplements for preventing gastrointestinal cancers. Cochrane Database Syst. Rev. 2008. [CrossRef] [PubMed]

4. Linden, S.; Sutton, P.; Karlsson, N.; Korolik, V.; McGuckin, M. Mucins in the mucosal barrier to infection. Mucosal Immunol. 2008, 1, 183-197. [CrossRef]

5. Ostedgaard, L.S.; Moninger, T.O.; McMenimen, J.D.; Sawin, N.M.; Parker, C.P.; Thornell, I.M.; Powers, L.S.; Gansemer, N.D.; Bouzek, D.C.; Cook, D.P. Gel-forming mucins form distinct morphologic structures in airways. Proc. Natl. Acad. Sci. USA 2017, 114, 6842-6847. [CrossRef]

6. Rachagani, S.; Torres, M.P.; Moniaux, N.; Batra, S.K. Current status of mucins in the diagnosis and therapy of cancer. Biofactors 2009, 35, 509-527. [CrossRef] [PubMed]

7. Gendler, S.; Burchell, J.; Duhig, T.; Lamport, D.; White, R.; Parker, M.; Taylor-Papadimitriou, J. Cloning of partial cDNA encoding differentiation and tumor-associated mucin glycoproteins expressed by human mammary epithelium. Proc. Natl. Acad. Sci. USA 1987, 84, 6060-6064. [CrossRef]

8. Lan, M.S.; Batra, S.K.; Qi, W.-N.; Metzgar, R.S.; Hollingsworth, M.A. Cloning and sequencing of a human pancreatic tumor mucin cDNA. J. Biol. Chem. 1990, 265, 15294-15299.

9. Ligtenberg, M.; Vos, H.; Gennissen, A.; Hilkens, J. Episialin, a carcinoma-associated mucin, is generated by a polymorphic gene encoding splice variants with alternative amino termini. J. Biol. Chem. 1990, 265, 5573-5578.

10. Siddiqui, J.; Abe, M.; Hayes, D.; Shani, E.; Yunis, E.; Kufe, D. Isolation and sequencing of a cDNA coding for the human DF3 breast carcinoma-associated antigen. Proc. Natl. Acad. Sci. USA 1988, 85, 2320-2323. [CrossRef] [PubMed]

11. Hattrup, C.L.; Gendler, S.J. Structure and function of the cell surface (tethered) mucins. Annu. Rev. Physiol. 2008, 70, 431-457. [CrossRef]

12. Gendler, S.J.; Spicer, A. Epithelial mucin genes. Annu. Rev. Physiol. 1995, 57, 607-634. [CrossRef]

13. Gendler, S.J. MUC1, the renaissance molecule. J. Mammary Gland Biol. Neoplasia 2001, 6, 339-353. [CrossRef]

14. Chang, J.-F.; Zhao, H.-L.; Phillips, J.; Greenburg, G. The epithelial mucin, MUC1, is expressed on resting T lymphocytes and can function as a negative regulator of T cell activation. Cell. Immunol. 2000, 201, 83-88. [CrossRef]

15. Yolken, R.H.; Peterson, J.A.; Vonderfecht, S.L.; Fouts, E.T.; Midthun, K.; Newburg, D.S. Human milk mucin inhibits rotavirus replication and prevents experimental gastroenteritis. J. Clin. Investig. 1992, 90, 1984-1991. [CrossRef] 
16. Schroten, H.; Hanisch, F.; Plogmann, R.; Hacker, J.; Uhlenbruck, G.; Nobis-Bosch, R.; Wahn, V. Inhibition of adhesion of S-fimbriated Escherichia coli to buccal epithelial cells by human milk fat globule membrane components: A novel aspect of the protective function of mucins in the nonimmunoglobulin fraction. Infect. Immun. 1992, 60, 2893-2899. [CrossRef] [PubMed]

17. Kufe, D.W. Mucins in cancer: Function, prognosis and therapy. Nat. Rev. Cancer 2009, 9, 874-885. [CrossRef] [PubMed]

18. Baruch, A.; Hartmann, M.-L.; Yoeli, M.; Adereth, Y.; Greenstein, S.; Stadler, Y.; Skornik, Y.; Zaretsky, J.; Smorodinsky, N.I.; Keydar, I. The breast cancer-associated MUC1 gene generates both a receptor and its cognate binding protein. Cancer Res. 1999, 59, 1552-1561.

19. Stasyk, T.; Huber, L.A. Spatio-temporal parameters of endosomal signaling in cancer: Implications for new treatment options. J. Cell. Biochem. 2016, 117, 836-843. [CrossRef]

20. Levitin, F.; Stern, O.; Weiss, M.; Gil-Henn, C.; Ziv, R.; Prokocimer, Z.; Smorodinsky, N.I.; Rubinstein, D.B.; Wreschner, D.H. The MUC1 SEA module is a self-cleaving domain. J. Biol. Chem. 2005, 280, 33374-33386. [CrossRef]

21. Parry, S.; Silverman, H.S.; McDermott, K.; Willis, A.; Hollingsworth, M.A.; Harris, A. Identification of MUC1 proteolytic cleavage sites in vivo. Biochem. Biophys. Res. Commun. 2001, 283, 715-720. [CrossRef]

22. Kufe, D.W. MUC1-C oncoprotein as a target in breast cancer: Activation of signaling pathways and therapeutic approaches. Oncogene 2013, 32, 1073-1081.

23. Bennett, E.P.; Mandel, U.; Clausen, H.; Gerken, T.A.; Fritz, T.A.; Tabak, L.A. Control of mucin-type O-glycosylation: A classification of the polypeptide GalNAc-transferase gene family. Glycobiology 2012, 22, 736-756. [CrossRef]

24. Movahedin, M.; Brooks, T.M.; Supekar, N.T.; Gokanapudi, N.; Boons, G.-J.; Brooks, C.L. Glycosylation of MUC1 influences the binding of a therapeutic antibody by altering the conformational equilibrium of the antigen. Glycobiology 2017, 27, 677-687. [CrossRef] [PubMed]

25. Piyush, T.; Rhodes, J.M.; Yu, L.-G. MUC1 O-glycosylation contributes to anoikis resistance in epithelial cancer cells. Cell Death Discov. 2017, 3, 1-9. [CrossRef]

26. Parry, S.; Hanisch, F.G.; Leir, S.-H.; Sutton-Smith, M.; Morris, H.R.; Dell, A.; Harris, A. N-Glycosylation of the MUC1 mucin in epithelial cells and secretions. Glycobiology 2006, 16, 623-634. [CrossRef]

27. Tian, E.; Ten Hagen, K.G. Recent insights into the biological roles of mucin-type O-glycosylation. Glycoconj. J. 2009, 26, 325-334. [CrossRef]

28. Ju, T.; Wang, Y.; Aryal, R.P.; Lehoux, S.D.; Ding, X.; Kudelka, M.R.; Cutler, C.; Zeng, J.; Wang, J.; Sun, X. T $\mathrm{n}$ and sialyl-Tn antigens, aberrant O-glycomics as human disease markers. Proteom. Clin. Appl. 2013, 7, 618-631. [CrossRef]

29. Clausen, H.; Bennett, E.P. A family of UDP-GalNAc: Polypeptide N-acetylgalactosaminyl-transferases control the initiation of mucin-type O-linked glycosylation. Glycobiology 1996, 6, 635-646. [CrossRef]

30. Breloy, I.; Hanisch, F.-G. Functional Roles of O-Glycosylation. Molecules 2018, 3063. [CrossRef]

31. Brockhausen, I. Mucin-type O-glycans in human colon and breast cancer: Glycodynamics and functions. EMBO Rep. 2006, 7, 599-604. [CrossRef] [PubMed]

32. Hanson, R.L.; Hollingsworth, M.A. Functional consequences of differential O-glycosylation of MUC1, MUC4, and MUC16 (downstream effects on signaling). Biomolecules 2016, 6, 34. [CrossRef]

33. Chandrasekaran, E.; Xue, J.; Xia, J.; Locke, R.D.; Patil, S.A.; Neelamegham, S.; Matta, K.L. Characterization of cancer associated mucin type O-glycans using the exchange sialylation properties of mammalian sialyltransferase ST3Gal-II. J. Proteome Res. 2012, 11, 2609-2618. [CrossRef]

34. Saeland, E.; Belo, A.I.; Mongera, S.; van Die, I.; Meijer, G.A.; van Kooyk, Y. Differential glycosylation of MUC1 and CEACAM5 between normal mucosa and tumour tissue of colon cancer patients. Int. J. Cancer 2012, 131, 117-128. [CrossRef]

35. Horm, T.M.; Schroeder, J.A. MUC1 and metastatic cancer: Expression, function and therapeutic targeting. Cell Adhes. Migr. 2013, 7, 187-198. [CrossRef]

36. Ghosh, S.K.; Pantazopoulos, P.; Medarova, Z.; Moore, A. Expression of underglycosylated MUC1 antigen in cancerous and adjacent normal breast tissues. Clin. Breast Cancer 2013, 13, 109-118. [CrossRef] [PubMed]

37. Taylor-Papadimitriou, J.; Burchell, J.M.; Graham, R.; Beatson, R. Latest developments in MUC1 immunotherapy. Biochem. Soc. Trans. 2018, 46, 659-668. [CrossRef] 
38. Posey, A.D., Jr.; Schwab, R.D.; Boesteanu, A.C.; Steentoft, C.; Mandel, U.; Engels, B.; Stone, J.D.; Madsen, T.D.; Schreiber, K.; Haines, K.M. Engineered CAR T cells targeting the cancer-associated Tn-glycoform of the membrane mucin MUC1 control adenocarcinoma. Immunity 2016, 44, 1444-1454. [CrossRef]

39. Pourjafar, M.; Samadi, P.; Khoshinani, H.M.; Saidijam, M. Are mimotope vaccines a good alternative to monoclonal antibodies? Immunotherapy 2019, 11, 795-800. [CrossRef]

40. Lau, S.K.; Weiss, L.M.; Chu, P.G. Differential expression of MUC1, MUC2, and MUC5AC in carcinomas of various sites: An immunohistochemical study. Am. J. Clin. Pathol. 2004, 122, 61-69. [CrossRef]

41. Nath, S.; Mukherjee, P. MUC1: A multifaceted oncoprotein with a key role in cancer progression. Trends Mol. Med. 2014, 20, 332-342. [CrossRef]

42. Bose, M.; Mukherjee, P. Microbe-MUC1 Crosstalk in Cancer-Associated Infections. Trends Mol. Med. 2020, 26, 324-336. [CrossRef] [PubMed]

43. Cheever, M.A.; Allison, J.P.; Ferris, A.S.; Finn, O.J.; Hastings, B.M.; Hecht, T.T.; Mellman, I.; Prindiville, S.A.; Viner, J.L.; Weiner, L.M. The prioritization of cancer antigens: A national cancer institute pilot project for the acceleration of translational research. Clin. Cancer Res. 2009, 15, 5323-5337. [CrossRef]

44. Zeng, Y.; Zhang, Q.; Zhang, Y.; Lu, M.; Liu, Y.; Zheng, T.; Feng, S.; Hao, M.; Shi, H. MUC1 predicts colorectal cancer metastasis: A systematic review and meta-analysis of case controlled studies. PLoS ONE 2015, 10, e0138049. [CrossRef]

45. Agata, N.; Ahmad, R.; Kawano, T.; Raina, D.; Kharbanda, S.; Kufe, D. MUC1 oncoprotein blocks death receptor-mediated apoptosis by inhibiting recruitment of caspase-8. Cancer Res. 2008, 68, 6136-6144. [CrossRef]

46. Yin, L.; Kosugi, M.; Kufe, D. Inhibition of the MUC1-C oncoprotein induces multiple myeloma cell death by down-regulating TIGAR expression and depleting NADPH. Blood J. Am. Soc. Hematol. 2012, 119, 810-816. [CrossRef]

47. Pochampalli, M.; El Bejjani, R.; Schroeder, J. MUC1 is a novel regulator of ErbB1 receptor trafficking. Oncogene 2007, 26, 1693-1701. [CrossRef]

48. Liu, X.; Caffrey, T.; Steele, M.; Mohr, A.; Singh, P.; Radhakrishnan, P.; Kelly, D.L.; Wen, Y.; Hollingsworth, M.A. MUC1 regulates cyclin D1 gene expression through p120 catenin and $\beta$-catenin. Oncogenesis 2014, 3, e107. [CrossRef]

49. Wei, X.; Xu, H.; Kufe, D. Human mucin 1 oncoprotein represses transcription of the p53 tumor suppressor gene. Cancer Res. 2007, 67, 1853-1858. [CrossRef]

50. Yin, L.; Huang, L.; Kufe, D. MUC1 oncoprotein activates the FOXO3a transcription factor in a survival response to oxidative stress. J. Biol. Chem. 2004, 279, 45721-45727. [CrossRef]

51. Ren, J.; Bharti, A.; Raina, D.; Chen, W.; Ahmad, R.; Kufe, D. MUC1 oncoprotein is targeted to mitochondria by heregulin-induced activation of c-Src and the molecular chaperone HSP90. Oncogene 2006, 25, 20-31. [CrossRef] [PubMed]

52. Raina, D.; Kharbanda, S.; Kufe, D. The MUC1 oncoprotein activates the anti-apoptotic phosphoinositide 3-kinase/Akt and Bcl-xL pathways in rat $3 Y 1$ fibroblasts. J. Biol. Chem. 2004, 279, 20607-20612. [CrossRef]

53. Satoh, S.; Hinoda, Y.; Hayashi, T.; Burdick, M.D.; Imai, K.; Hollingsworth, M.A. Enhancement of metastatic properties of pancreatic cancer cells by MUC1 gene encoding an anti-adhesion molecule. Int. J. Cancer 2000, 88, 507-518. [CrossRef]

54. Regimbald, L.H.; Pilarski, L.M.; Longenecker, B.M.; Reddish, M.A.; Zimmermann, G.; Hugh, J.C. The breast mucin MUC1 as a novel adhesion ligand for endothelial intercellular adhesion molecule 1 in breast cancer. Cancer Res. 1996, 56, 4244-4249.

55. Nath, S.; Daneshvar, K.; Roy, L.; Grover, P.; Kidiyoor, A.; Mosley, L.; Sahraei, M.; Mukherjee, P. MUC1 induces drug resistance in pancreatic cancer cells via upregulation of multidrug resistance genes. Oncogenesis 2013, 2, e51. [CrossRef]

56. Singh, P.K.; Wen, Y.; Swanson, B.J.; Shanmugam, K.; Kazlauskas, A.; Cerny, R.L.; Gendler, S.J.; Hollingsworth, M.A. Platelet-derived growth factor receptor $\beta$-mediated phosphorylation of MUC1 enhances invasiveness in pancreatic adenocarcinoma cells. Cancer Res. 2007, 67, 5201-5210. [CrossRef]

57. Roy, L.D.; Sahraei, M.; Subramani, D.B.; Besmer, D.; Nath, S.; Tinder, T.L.; Bajaj, E.; Shanmugam, K.; Lee, Y.Y.; Hwang, S.I. MUC1 enhances invasiveness of pancreatic cancer cells by inducing epithelial to mesenchymal transition. Oncogene 2011, 30, 1449-1459. [CrossRef] [PubMed] 
58. Sahraei, M.; Roy, L.D.; Curry, J.M.; Teresa, T.L.; Nath, S.; Besmer, D.; Kidiyoor, A.; Dalia, R.; Gendler, S.J.; Mukherjee, P. MUC1 regulates PDGFA expression during pancreatic cancer progression. Oncogene 2012, 31, 4935-4945. [CrossRef]

59. Grover, P.; Nath, S.; Nye, M.D.; Zhou, R.; Ahmad, M.; Mukherjee, P. SMAD4-independent activation of TGF- $\beta$ signaling by MUC1 in a human pancreatic cancer cell line. Oncotarget 2018, 9, 6897. [CrossRef] [PubMed]

60. Grover, P.; Nath, S.; Bose, M.; Sanders, A.J.; Brouwer, C.; Fnu, N.; Zhou, R.; Yazdanifar, M.; Ahmed, M.; Wu, S.-T. Tumor-Associated MUC1 Regulates TGF- $\beta$ Signaling and Function in Pancreatic Ductal Adenocarcinoma. bioRxiv 2020. [CrossRef]

61. Wang, X.-T.; Kong, F.-B.; Mai, W.; Li, L.; Pang, L.-M. MUC1 immunohistochemical expression as a prognostic factor in gastric cancer: Meta-analysis. Dis. Markers 2016, 9421571. [CrossRef] [PubMed]

62. Scott, A.M.; Allison, J.P.; Wolchok, J.D. Monoclonal antibodies in cancer therapy. Cancer Immun. Arch. 2012, 12, 14-22.

63. Weiner, L.M.; Murray, J.C.; Shuptrine, C.W. Antibody-based immunotherapy of cancer. Cell 2012, 148, 1081-1084. [CrossRef]

64. Redman, J.; Hill, E.; AlDeghaither, D.; Weiner, L. Mechanisms of action of therapeutic antibodies for cancer. Mol. Immunol. 2015, 67, 28-45. [CrossRef]

65. Shuptrine, C.W.; Surana, R.; Weiner, L.M. Monoclonal antibodies for the treatment of cancer. In Seminars in Cancer Biology; Elsevier: Amsterdam, The Netherlands, 2012; pp. 3-13.

66. Samadi, P.; Saki, S.; Dermani, F.K.; Pourjafar, M.; Saidijam, M. Emerging ways to treat breast cancer: Will promises be met? Cell. Oncol. 2018, 41, 605-621. [CrossRef]

67. Doi, M.; Yokoyama, A.; Kondo, K.; Ohnishi, H.; Ishikawa, N.; Hattori, N.; Kohno, N. Anti-tumor effect of the anti-KL-6/MUC1 monoclonal antibody through exposure of surface molecules by MUC1 capping. Cancer Sci. 2006, 97, 420-429. [CrossRef]

68. Ohyabu, N.; Hinou, H.; Matsushita, T.; Izumi, R.; Shimizu, H.; Kawamoto, K.; Numata, Y.; Togame, H.; Takemoto, H.; Kondo, H. An essential epitope of anti-MUC1 monoclonal antibody KL-6 revealed by focused glycopeptide library. J. Am. Chem. Soc. 2009, 131, 17102-17109. [CrossRef]

69. Namba, M.; Hattori, N.; Hamada, H.; Yamaguchi, K.; Okamoto, Y.; Nakashima, T.; Masuda, T.; Sakamoto, S.; Horimasu, Y.; Miyamoto, S. Anti-KL-6/MUC1 monoclonal antibody reverses resistance to trastuzumab-mediated antibody-dependent cell-mediated cytotoxicity by capping MUC1. Cancer Lett. 2019, 442, 31-39. [CrossRef] [PubMed]

70. Yamamoto, M.; Bhavanandan, V.; Nakamori, S.; Irimura, T. A novel monoclonal antibody specific for sialylated MUC1 mucin. Jpn. J. Cancer Res. 1996, 87, 488-496. [CrossRef]

71. Suzuki, H.; Shoda, J.; Kawamoto, T.; Shinozaki, E.; Miyahara, N.; Hotta, S.; Iizuka, Y.; Nakahara, A.; Tanaka, N.; Yanaka, A. Expression of MUC1 recognized by monoclonal antibody MY. 1E12 is a useful biomarker for tumor aggressiveness of advanced colon carcinoma. Clin. Exp. Metastasis 2004, 21, 321-329. [CrossRef]

72. Yoshimura, Y.; Denda-Nagai, K.; Takahashi, Y.; Nagashima, I.; Shimizu, H.; Kishimoto, T.; Noji, M.; Shichino, S.; Chiba, Y.; Irimura, T. Products of Chemoenzymatic Synthesis Representing MUC1 Tandem Repeat Unit with T-, ST-or STn-antigen Revealed Distinct Specificities of Anti-MUC1 Antibodies. Sci. Rep. 2019, 9, 1-12. [CrossRef]

73. Muguruma, N.; Ito, S. Labeled anti-mucin antibody detectable by infrared-fluorescence endoscopy. Cancer Biomark. 2008, 4, 321-328. [CrossRef]

74. Tarp, M.A.; Sørensen, A.L.; Mandel, U.; Paulsen, H.; Burchell, J.; Taylor-Papadimitriou, J.; Clausen, H. Identification of a novel cancer-specific immunodominant glycopeptide epitope in the MUC1 tandem repeat. Glycobiology 2007, 17, 197-209. [CrossRef] [PubMed]

75. Wu, G.; Maharjan, S.; Kim, D.; Kim, J.N.; Park, B.K.; Koh, H.; Moon, K.; Lee, Y.; Kwon, H.-J. A novel monoclonal antibody targets Mucin1 and attenuates growth in pancreatic cancer model. Int. J. Mol. Sci. 2018, 19, 2004. [CrossRef]

76. Wu, G.; Kim, D.; Kim, J.N.; Park, S.; Maharjan, S.; Koh, H.; Moon, K.; Lee, Y.; Kwon, H.-J. A Mucin1 C-terminal subunit-directed monoclonal antibody targets overexpressed Mucin1 in breast cancer. Theranostics 2018, 8, 78. [CrossRef] 
77. Tinder, T.L.; Subramani, D.B.; Basu, G.D.; Bradley, J.M.; Schettini, J.; Million, A.; Skaar, T.; Mukherjee, P. MUC1 enhances tumor progression and contributes toward immunosuppression in a mouse model of spontaneous pancreatic adenocarcinoma. J. Immunol. 2008, 181, 3116-3125. [CrossRef]

78. Mukherjee, P.; Madsen, C.S.; Ginardi, A.R.; Tinder, T.L.; Jacobs, F.; Parker, J.; Agrawal, B.; Longenecker, B.M.; Gendler, S.J. Mucin 1-specific immunotherapy in a mouse model of spontaneous breast cancer. J. Immunother. 2003, 26, 47-62. [CrossRef]

79. Dréau, D.; Moore, L.J.; Wu, M.; Roy, L.D.; Dillion, L.; Porter, T.; Puri, R.; Momin, N.; Wittrup, K.D.; Mukherjee, P. Combining the specific anti-MUC1 antibody TAB004 and Lip-MSA-IL-2 limits pancreatic cancer progression in immune competent murine models of pancreatic ductal adenocarcinoma. Front. Oncol. 2019, 9, 330. [CrossRef]

80. Moore, L.J.; Roy, L.D.; Zhou, R.; Grover, P.; Wu, S.-T.; Curry, J.M.; Dillon, L.M.; Puri, P.M.; Yazdanifar, M.; Puri, R. Antibody-guided in vivo imaging for early detection of mammary gland tumors. Transl. Oncol. 2016, 9, 295-305. [CrossRef]

81. Bose, M.; Mukherjee, P. A Novel Antibody Blocks Anti-Apoptotic Activity of MUC1 in Pancreatic Cancer Cell Lines. Cancer Res. 2019, 79 (Suppl. 13), 2052. [CrossRef]

82. Yazdanifar, M.; Zhou, R.; Grover, P.; Williams, C.; Bose, M.; Moore, L.J.; Wu, S.-t.; Maher, J.; Dreau, D.; Mukherjee, P. Overcoming Immunological Resistance Enhances the Efficacy of a Novel Anti-tMUC1-CAR T Cell Treatment against Pancreatic Ductal Adenocarcinoma. Cells 2019, 8, 1070. [CrossRef]

83. Calvete, J.A.; Newell, D.R.; Wright, A.F.; Rose, M.S. In vitro and in vivo antitumor activity of ZENECA ZD0490, a recombinant ricin A-chain immunotoxin for the treatment of colorectal cancer. Cancer Res. 1994, $54,4684-4690$.

84. Baeckström, D.; Hansson, G.C.; Nilsson, O.; Johansson, C.; Gendler, S.J.; Lindholm, L. Purification and characterization of a membrane-bound and a secreted mucin-type glycoprotein carrying the carcinoma-associated sialyl-Lea epitope on distinct core proteins. J. Biol. Chem. 1991, 266, 21537-21547.

85. Tolcher, A.W.; Ochoa, L.; Hammond, L.A.; Patnaik, A.; Edwards, T.; Takimoto, C.; Smith, L.; de Bono, J.; Schwartz, G.; Mays, T. Cantuzumab mertansine, a maytansinoid immunoconjugate directed to the CanAg antigen: A phase, I.; pharmacokinetic, and biologic correlative study. J. Clin. Oncol. 2003, 21, 211-222. [CrossRef]

86. Rodon, J.; Garrison, M.; Hammond, L.A.; De Bono, J.; Smith, L.; Forero, L.; Hao, D.; Takimoto, C.; Lambert, J.M.; Pandite, L. Cantuzumab mertansine in a three-times a week schedule: A phase I and pharmacokinetic study. Cancer Chemother. Pharmacol. 2008, 62,911-919. [CrossRef]

87. Mita, M.; Ricart, A.; Mita, A.; Patnaik, A.; Sarantopoulos, J.; Sankhala, K.; Fram, R.; Qin, A.; Watermill, J.; Tolcher, A. A phase I study of a CanAg-targeted immunoconjugate, huC242-DM4, in patients with Can Ag-expressing solid tumors. J. Clin. Oncol. 2007, 25 (Suppl. 18), 3062. [CrossRef]

88. Goff, L.; Papadopoulos, K.; Posey, J.; Phan, A.; Patnaik, A.; Miller, J.; Zildjian, S.; O’Leary, J.; Qin, A.; Tolcher, A. A phase II study of IMGN242 (huC242-DM4) in patients with CanAg-positive gastric or gastroesophageal (GE) junction cancer. J. Clin. Oncol. 2009, 27 (Suppl. 15), e15625. [CrossRef]

89. Gold, D.V.; Cardillo, T.; Vardi, Y.; Blumenthal, R. Radioimmunotherapy of experimental pancreatic cancer with 131I-labeled monoclonal antibody PAM4. Int. J. Cancer 1997, 71, 660-667. [CrossRef]

90. Cardillo, T.M.; Ying, Z.; Gold, D.V. Therapeutic advantage of 90yttrium-versus 131iodine-labeled PAM4 antibody in experimental pancreatic cancer. Clin. Cancer Res. 2001, 7, 3186-3192. [PubMed]

91. Gold, D.V.; Karanjawala, Z.; Modrak, D.E.; Goldenberg, D.M.; Hruban, R.H. PAM4-reactive MUC1 is a biomarker for early pancreatic adenocarcinoma. Clin. Cancer Res. 2007, 13, 7380-7387. [CrossRef] [PubMed]

92. Gulec, S.; Pennington, K.; Bruetman, D.; Garl, S.; Horne, H.; Gold, D.; Wegener, W.; Goldenberg, D. A phase-I study of 90Y-hPAM4 (humanized anti-MUC1 monoclonal antibody) in patients with unresectable and metastatic pancreatic cancer. J. Nucl. Med. 2007, 48 (Suppl. 2), 393p.

93. Picozzi, V.J.; Ramanathan, R.K.; Lowery, M.A.; Ocean, A.J.; Mitchel, E.P.; O’Neil, B.H.; Guarino, M.J.; Conkling, P.R.; Cohen, S.J.; Bahary, N. 90Y-clivatuzumab tetraxetan with or without low-dose gemcitabine: A phase Ib study in patients with metastatic pancreatic cancer after two or more prior therapies. Eur. J. Cancer 2015, 51, 1857-1864. [CrossRef]

94. Dian, D.; Janni, W.; Kuhn, C.; Mayr, D.; Karsten, U.; Mylonas, I.; Friese, K.; Jeschke, U. Evaluation of a novel anti-mucin 1 (MUC1) antibody (PankoMab) as a potential diagnostic tool in human ductal breast cancer; comparison with two established antibodies. Oncol. Res. Treat. 2009, 32, 238-244. [CrossRef] 
95. Danielczyk, A.; Stahn, R.; Faulstich, D.; Löffler, A.; Märten, A.; Karsten, U.; Goletz, S. PankoMab: A potent new generation anti-tumour MUC1 antibody. Cancer Immunol. Immunother. 2006, 55, 1337-1347. [CrossRef]

96. Fiedler, W.; DeDosso, S.; Cresta, S.; Weidmann, J.; Tessari, A.; Salzberg, M.; Dietrich, B.; Baumeister, H.; Goletz, S.; Gianni, L. A phase I study of PankoMab-GEX, a humanised glyco-optimised monoclonal antibody to a novel tumour-specific MUC1 glycopeptide epitope in patients with advanced carcinomas. Eur. J. Cancer 2016, 63, 55-63. [CrossRef] [PubMed]

97. Ledermann, J.; Sehouli, J.; Zurawski, B.; Raspagliesi, F.; De Giorgi, U.; Banerjee, S.; Arranz Arija, J.; Romeo Marin, M.; Lisyanskaya, A.; Póka, R. LBA41A double-blind, placebo-controlled, randomized, phase 2 study to evaluate the efficacy and safety of switch maintenance therapy with the anti-TA-MUC1 antibody PankoMab-GEX after chemotherapy in patients with recurrent epithelial ovarian carcinoma. Ann. Oncol. 2017, 28 (Suppl. 5), v605-v649. [CrossRef]

98. Runcie, K.; Budman, D.R.; John, V.; Seetharamu, N. Bi-specific and tri-specific antibodies-the next big thing in solid tumor therapeutics. Mol. Med. 2018, 24, 50. [CrossRef]

99. Mehla, K.; Tremayne, J.; Grunkemeyer, J.A.; O'Connell, K.A.; Steele, M.M.; Caffrey, T.C.; Zhu, X.; Yu, F.; Singh, P.K.; Schultes, B.C. Combination of mAb-AR20. 5, anti-PD-L1 and PolyICLC inhibits tumor progression and prolongs survival of MUC1. Tg mice challenged with pancreatic tumors. Cancer Immunol. Immunother. 2018, 67, 445-457. [CrossRef]

100. De Bono, J.; Rha, S.Y.; Stephenson, J.; Schultes, B.; Monroe, P.; Eckhardt, G.; Hammond, L.; Whiteside, T.; Nicodemus, C.; Cermak, J. Phase I trial of a murine antibody to MUC1 in patients with metastatic cancer: Evidence for the activation of humoral and cellular antitumor immunity. Ann. Oncol. 2004, 15, 1825-1833. [CrossRef]

101. Ibrahim, N.K.; Yariz, K.O.; Bondarenko, I.; Manikhas, A.; Semiglazov, V.; Alyasova, A.; Komisarenko, V.; Shparyk, Y.; Murray, J.L.; Jones, D. Randomized phase II trial of letrozole plus anti-MUC1 antibody AS1402 in hormone receptor-positive locally advanced or metastatic breast cancer. Clin. Cancer Res. 2011, 17, 6822-6830. [CrossRef]

102. Corraliza-Gorjón, I.; Somovilla-Crespo, B.; Santamaria, S.; Garcia-Sanz, J.A.; Kremer, L. New strategies using antibody combinations to increase cancer treatment effectiveness. Front. Immunol. 2017, 8, 1804. [CrossRef]

103. Venepalli, N.K.; Gandhi, C.C.; Ozer, H.; Ho, D.; Lu, Y.; Xie, H.; Berg, S.A.; Chowdhery, R.A.; Gargano, M.A.; Braun, A.H. Phase Ib study of PGG beta glucan in combination with anti-MUC1 antibody (BTH1704) and gemcitabine for the treatment of advanced pancreatic cancer. Am. Soc. Clin. Oncol. 2015, 33. [CrossRef]

104. Gold, D.V.; Newsome, G.; Liu, D.; Goldenberg, D.M. Mapping PAM4 (clivatuzumab), a monoclonal antibody in clinical trials for early detection and therapy of pancreatic ductal adenocarcinoma, to MUC5AC mucin. Mol. Cancer 2013, 12, 143. [CrossRef]

105. Gold, D.V.; Cardillo, T.; Goldenberg, D.M.; Sharkey, R.M. Localization of pancreatic cancer with radiolabeled monoclonal antibody PAM4. Crit. Rev. Oncol./Hematol. 2001, 39, 147-154. [CrossRef]

106. Hisatsune, A.; Nakayama, H.; Kawasaki, M.; Horie, I.; Miyata, T.; Isohama, Y.; Kim, K.C.; Katsuki, H. Anti-MUC1 antibody inhibits EGF receptor signaling in cancer cells. Biochem. Biophys. Res. Commun. 2011, 405, 377-381. [CrossRef] [PubMed]

107. Hollingsworth, M.A.; Swanson, B.J. Mucins in cancer: Protection and control of the cell surface. Nat. Rev. Cancer 2004, 4, 45-60. [CrossRef] [PubMed]

108. Vivero-Escoto, J.L.; Jeffords, L.M.; Dréau, D.; Alvarez-Berrios, M.; Mukherjee, P. Mucin1 antibody-conjugated dye-doped mesoporous silica nanoparticles for breast cancer detection in vivo. In Colloidal Nanoparticles for Biomedical Applications XII: 2017; International Society for Optics and Photonics: San Francisco, CA, USA, 2017; p. 100780B.

109. Curry, J.M.; Thompson, K.J.; Rao, S.G.; Besmer, D.M.; Murphy, A.M.; Grdzelishvili, V.Z.; Ahrens, W.A.; McKillop, I.H.; Sindram, D.; Iannitti, D.A. The use of a novel MUC1 antibody to identify cancer stem cells and circulating MUC1 in mice and patients with pancreatic cancer. J. Surg. Oncol. 2013, 107, 713-722. [CrossRef]

110. Kelly, V.J.; Wu, S.-T.; Gottumukkala, V.; Coelho, R.; Palmer, K.; Nair, S.; Erick, T.; Puri, R.; Ilovich, O.; Mukherjee, P. Preclinical evaluation of an 111In/225Ac theranostic targeting transformed MUC1 for triple negative breast cancer. Theranostics 2020, 10, 6946. [CrossRef] 
111. Yonezawa, S.; Kitajima, S.; Higashi, M.; Osako, M.; Horinouchi, M.; Yokoyama, S.; Kitamoto, S.; Yamada, N.; Tamura, Y.; Shimizu, T. A novel anti-MUC1 antibody against the MUC1 cytoplasmic tail domain: Use in sensitive identification of poorly differentiated cells in adenocarcinoma of the stomach. Gastric Cancer 2012, 15, 370-381. [CrossRef]

112. Qi, W.; Schultes, B.C.; Liu, D.; Kuzma, M.; Decker, W.; Madiyalakan, R. Characterization of an anti-MUC1 monoclonal antibody with potential as a cancer vaccine. Hybrid. Hybridomics 2001, 20, 313-324. [CrossRef]

113. Kearse, K.P.; Smith, N.L.; Semer, D.A.; Eagles, L.; Finley, J.L.; Kazmierczak, S.; Kovacs, C.J.; Rodriguez, A.A.; Kellogg-Wennerberg, A.E. Monoclonal antibody DS6 detects a tumor-associated sialoglycotope expressed on human serous ovarian carcinomas. Int. J. Cancer 2000, 88, 866-872. [CrossRef]

114. Trombe, M.; Caron, A.; Tellier, A.; Carrez, C.; Guérif, S.; Clavier, S.; Karst, N.; Saarinen, J.; Satomaa, T.; Pitkänen, V. Preclinical Activity of an Antibody Drug Conjugate Targeting Tumor Specificmuc1 Structural Peptide-Glycotope. Cancer Res. 2019, 235. [CrossRef]

115. Gomez-Roca, C.A.; Boni, V.; Moreno, V.; Morris, J.C.; Delord, J.-P.; Calvo, E.; Papadopoulos, K.P.; Rixe, O.; Cohen, P.; Tellier, A. A phase I study of SAR566658, an anti CA6-antibody drug conjugate (ADC), in patients (Pts) with CA6-positive advanced solid tumors (STs) (NCT01156870). Am. Soc. Clin. Oncol. 2016, 34, 2511. [CrossRef]

116. St. Croix, B.; Sheehan, C.; Rak, J.W.; Flørenes, V.A.; Slingerland, J.M.; Kerbel, R.S. E-cadherin-dependent growth suppression is mediated by the cyclin-dependent kinase inhibitor p27KIP1. J. Cell Biol. 1998, 142, 557-571. [CrossRef] [PubMed]

117. Matsumura, K.; Niki, I.; Tian, H.; Takuma, M.; Hongo, N.; Matsumoto, S.; Mori, H. Radioimmunoscintigraphy of pancreatic cancer in tumor-bearing athymic nude mice using $99 \mathrm{~m}$ technetium-labeled anti-KL-6/MUC1 antibody. Radiat. Med. 2008, 26, 133-139. [CrossRef]

118. Li, Y.; Zhou, C.; Li, J.; Liu, J.; Lin, L.; Li, L.; Cao, D.; Li, Q.; Wang, Z. Single domain based bispecific antibody, Muc1-Bi-1, and its humanized form, Muc1-Bi-2, induce potent cancer cell killing in muc1 positive tumor cells. PLoS ONE 2018, 13, e0191024. [CrossRef]

119. Kodama, H.; Suzuki, M.; Katayose, Y.; Shinoda, M.; Sakurai, N.; Takemura, S.-I.; Yoshida, H.; Saeki, H.; Asano, R.; Ichiyama, M. Specific and effective targeting cancer immunotherapy with a combination of three bispecific antibodies. Immunol. Lett. 2002, 81, 99-106. [CrossRef]

120. Hinoda, Y.; Nakagawa, N.; Ohe, Y.; Kakiuchi, H.; Tsujisaki, M.; Imai, K.; Yachi, A. Recognition of the polypeptide core of mucin by monoclonal antibody MUSE11 against an adenocarcinoma-associated antigen. Jpn. J. Cancer Res. 1990, 81, 1206-1209. [CrossRef]

121. Katayose, Y.; Kudo, T.; Suzuki, M.; Shinoda, M.; Saijyo, S.; Sakurai, N.; Saeki, H.; Fukuhara, K.; Imai, K.; Matsuno, S. MUC1-specific targeting immunotherapy with bispecific antibodies: Inhibition of xenografted human bile duct carcinoma growth. Cancer Res. 1996, 56, 4205-4212.

122. Takemura, S.-I.; Asano, R.; Tsumoto, K.; Ebara, S.; Sakurai, N.; Katayose, Y.; Kodama, H.; Yoshida, H.; Suzuki, M.; Imai, K. Construction of a diabody (small recombinant bispecific antibody) using a refolding system. Protein Eng. 2000, 13, 583-588. [CrossRef]

123. Takemura, S.-I.; Kudo, T.; Asano, R.; Suzuki, M.; Tsumoto, K.; Sakurai, N.; Katayose, Y.; Kodama, H.; Yoshida, H.; Ebara, S. A mutated superantigen SEA D227A fusion diabody specific to MUC1 and CD3 in targeted cancer immunotherapy for bile duct carcinoma. Cancer Immunol. Immunother. 2002, 51, 33-44. [CrossRef]

124. Schuhmacher, J.; Klivényi, G.; Kaul, S.; Henze, M.; Matys, R.; Hauser, H.; Clorius, J. Pretargeting of human mammary carcinoma xenografts with bispecific anti-MUC1/anti-Ga chelate antibodies and immunoscintigraphy with PET. Nucl. Med. Biol. 2001, 28, 821-828. [CrossRef]

125. King, T.; Posey, A. Co-expression of an engineered cell-surface sialidase by CART cells improves anti-cancer activity of NK cells in solid tumors. Cytotherapy 2019, 21, S27. [CrossRef]

126. Brooks, C.L.; Schietinger, A.; Borisova, S.N.; Kufer, P.; Okon, M.; Hirama, T.; MacKenzie, C.R.; Wang, L.-X.; Schreiber, H.; Evans, S.V. Antibody recognition of a unique tumor-specific glycopeptide antigen. Proc. Natl. Acad. Sci. USA 2010, 107, 10056-10061. [CrossRef]

127. Borgert, A.; Heimburg-Molinaro, J.; Song, X.; Lasanajak, Y.; Ju, T.; Liu, M.; Thompson, P.; Ragupathi, G.; Barany, G.; Smith, D.F. Deciphering structural elements of mucin glycoprotein recognition. ACS Chem. Biol. 2012, 7, 1031-1039. [CrossRef] 
128. Springer, G.F. Immunoreactive T and Tn epitopes in cancer diagnosis, prognosis, and immunotherapy. J. Mol. Med. 1997, 75, 594-602. [CrossRef] [PubMed]

129. Kudelka, M.R.; Ju, T.; Heimburg-Molinaro, J.; Cummings, R.D. Simple sugars to complex disease-Mucin-type O-glycans in cancer. In Advances in Cancer Research; Elsevier: Amsterdam, The Netherlands, 2015; Volume 126, pp. 53-135.

130. Karsten, U.; Serttas, N.; Paulsen, H.; Danielczyk, A.; Goletz, S. Binding patterns of DTR-specific antibodies reveal a glycosylation-conditioned tumor-specific epitope of the epithelial mucin (MUC1). Glycobiology 2004, 14, 681-692. [CrossRef]

131. Matsushita, T.; Takada, W.; Igarashi, K.; Naruchi, K.; Miyoshi, R.; Garcia-Martin, F.; Amano, M.; Hinou, H.; Nishimura, S.-I. A straightforward protocol for the preparation of high performance microarray displaying synthetic MUC1 glycopeptides. Biochim. Biophys. Acta (BBA)-Gen. Subj. 2014, 1840, 1105-1116. [CrossRef]

132. Rangappa, S.; Artigas, G.; Miyoshi, R.; Yokoi, Y.; Hayakawa, S.; Garcia-Martin, F.; Hinou, H.; Nishimura, S.-I. Effects of the multiple O-glycosylation states on antibody recognition of the immunodominant motif in MUC1 extracellular tandem repeats. MedChem Comm 2016, 7, 1102-1122. [CrossRef]

133. Martínez-Sáez, N.; Castro-López, J.; Valero-González, J.; Madariaga, D.; Compañón, I.; Somovilla, V.J.; Salvadó, M.; Asensio, J.L.; Jiménez-Barbero, J.; Avenoza, A. Deciphering the Non-equivalence of serine and threonine O-glycosylation points: Implications for molecular recognition of the Tn antigen by an anti-MUC1 antibody. Angew. Chem. Int. Ed. 2015, 54, 9830-9834. [CrossRef]

134. Wakui, H.; Tanaka, Y.; Ose, T.; Matsumoto, I.; Kato, K.; Min, Y.; Tachibana, T.; Sato, M.; Naruchi, K.; Martin, F.G. A straightforward approach to antibodies recognising cancer specific glycopeptidic neoepitopes. Chem. Sci. 2020, 11, 4999-5006. [CrossRef]

135. Thie, H.; Toleikis, L.; Li, J.; von Wasielewski, R.; Bastert, G.; Schirrmann, T.; Esteves, I.T.; Behrens, C.K.; Fournes, B.; Fournier, N. Rise and fall of an anti-MUC1 specific antibody. PLoS ONE 2011, 6, e15921. [CrossRef]

136. Moreno, M.; Bontkes, H.J.; Scheper, R.J.; Kenemans, P.; Verheijen, R.H.; von Mensdorff-Pouilly, S. High level of MUC1 in serum of ovarian and breast cancer patients inhibits huHMFG-1 dependent cell-mediated cytotoxicity (ADCC). Cancer Lett. 2007, 257, 47-55. [CrossRef] [PubMed]

137. Tang, Y.; Cui, X.; Xiao, H.; Qi, S.; Hu, X.; Yu, Q.; Shi, G.; Zhang, X.; Gu, J.; Yu, Y. Binding of circulating anti-MUC1 antibody and serum MUC1 antigen in stage IV breast cancer. Mol. Med. Rep. 2017, 15, 2659-2664. [CrossRef] [PubMed]

138. Treon, S.P.; Maimonis, P.; Bua, D.; Young, G.; Raje, N.; Mollick, J.; Chauhan, D.; Tai, Y.-T.; Hideshima, T.; Shima, Y. Elevated soluble MUC1 levels and decreased anti-MUC1 antibody levels in patients with multiple myeloma. Blood J. Am. Soc. Hematol. 2000, 96, 3147-3153.

139. Storr, S.J.; Royle, L.; Chapman, C.J.; Hamid, U.M.A.; Robertson, J.F.; Murray, A.; Dwek, R.A.; Rudd, P.M. The O-linked glycosylation of secretory/shed MUC1 from an advanced breast cancer patient's serum. Glycobiology 2008, 18, 456-462. [CrossRef]

140. Pegram, M.; Borges, V.; Fuloria, J.; Ibrahim, N.; Shapiro, C.; Perez, E.; Wang, K.; Schaedeli Stark, F.; Yeon, C.; Courtenay-Luck, N. Phase I pharmacokinetics (PK) of humanized anti-MUC-1 antibody R1550. J. Clin. Oncol. 2006, 24 (Suppl. 18), 2533. [CrossRef]

141. Zhou, D.; Xu, L.; Huang, W.; Tonn, T. Epitopes of MUC1 tandem repeats in cancer as revealed by antibody crystallography: Toward glycopeptide signature-guided therapy. Molecules 2018, 23, 1326. [CrossRef]

142. Sørensen, A.L.; Reis, C.A.; Tarp, M.A.; Mandel, U.; Ramachandran, K.; Sankaranarayanan, V.; Schwientek, T.; Graham, R.; Taylor-Papadimitriou, J.; Hollingsworth, M.A. Chemoenzymatically synthesized multimeric Tn/STn MUC1 glycopeptides elicit cancer-specific anti-MUC1 antibody responses and override tolerance. Glycobiology 2006, 16, 96-107. [CrossRef]

143. Rivalland, G.; Loveland, B.; Mitchell, P. Update on Mucin-1 immunotherapy in cancer: A clinical perspective. Expert Opin. Biol. Ther. 2015, 15, 1773-1787. [CrossRef]

144. Singh, R.; Bandyopadhyay, D. MUC1: A target molecule for cancer therapy. Cancer Biol. Ther. 2007, 6, 481-486. [CrossRef]

145. McGuckin, M.A.; Hurst, T.G.; Ward, B.G. Heterogeneity in production, secretion and glycosylation of MUC1 epithelial mucin by primary cultures of ovarian carcinoma. Int. J. Cancer 1995, 63, 412-418. [CrossRef] 
146. Walsh, M.D.; Luckie, S.M.; Cummings, M.C.; Antalis, T.M.; McGuckin, M.A. Heterogeneity of MUC1 expression by human breast carcinoma cell lines in vivo and in vitro. Breast Cancer Res. Treat. 1999, 58, 253-264. [CrossRef] [PubMed]

147. Zhao, Q.; Piyush, T.; Chen, C.; Hollingsworth, M.A.; Hilkens, J.; Rhodes, J.M.; Yu, L.-G. MUC1 extracellular domain confers resistance of epithelial cancer cells to anoikis. Cell Death Dis. 2014, 5, e1438. [CrossRef] [PubMed]

148. Pichinuk, E.; Benhar, I.; Jacobi, O.; Chalik, M.; Weiss, L.; Ziv, R.; Sympson, C.; Karwa, A.; Smorodinsky, N.I.; Rubinstein, D.B. Antibody targeting of cell-bound MUC1 SEA domain kills tumor cells. Cancer Res. 2012, 72, 3324-3336. [CrossRef]

149. Madsen, C.B.; Wandall, H.H.; Pedersen, A.E. Potential for novel MUC1 glycopeptide-specific antibody in passive cancer immunotherapy. Immunopharmacol. Immunotoxicol. 2013, 35, 649-652. [CrossRef]

150. Reilly, R.M.; Sandhu, J.; Alvarez-Diez, T.M.; Gallinger, S.; Kirsh, J.; Stern, H. Problems of delivery of monoclonal antibodies. Clin. Pharmacokinet. 1995, 28, 126-142. [CrossRef] [PubMed]

151. Sonbol, M.B.; Ahn, D.H.; Goldstein, D.; Okusaka, T.; Tabernero, J.; Macarulla, T.; Reni, M.; Li, C.-P.; O’Neil, B.; Van Cutsem, E. CanStem111P trial: A Phase III study of napabucasin plus nab-paclitaxel with gemcitabine. Future Oncol. 2019, 15, 1295-1302. [CrossRef]

152. Bose, M.; Vora, A.; Colleton, T.; Mukherjee, P. MUC1 Confers Sensitivity to STAT-3 Inhibitor Napabucasin in Pancreatic Ductal Adenocarcinoma Cells. Cancer Res. 2020, 1837. [CrossRef]

Publisher's Note: MDPI stays neutral with regard to jurisdictional claims in published maps and institutional affiliations. 